\title{
Bioned. Lib.
}

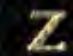

5331

F81 4e

876-83 
$\frac{1}{9 x y}=$

an $1 \mathrm{NS}$
4hI low Midown

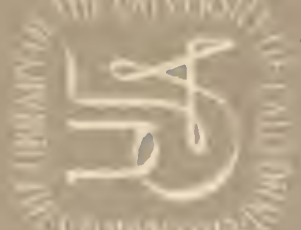

orgathinamitie

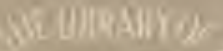

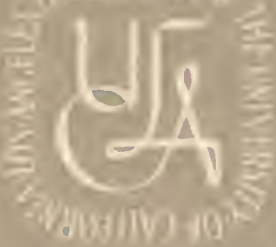

s.M Dillagy

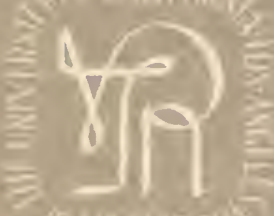

colinatias

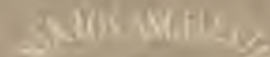

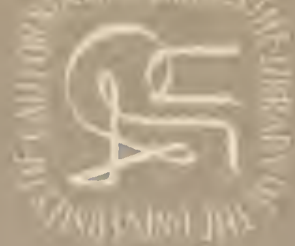

Weaskini jor

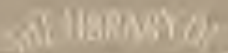
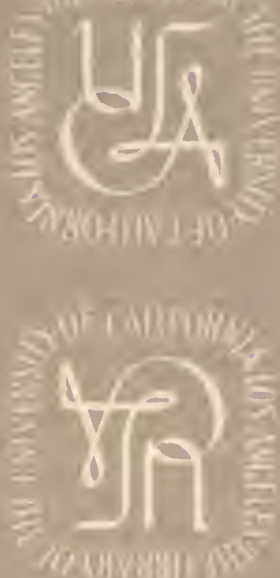

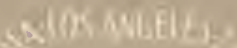

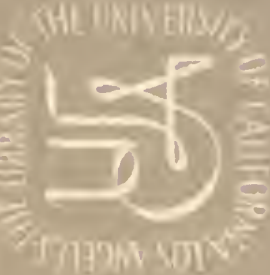

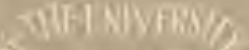

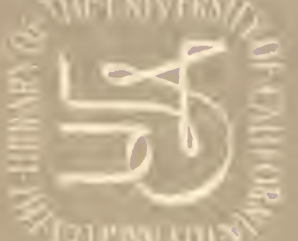

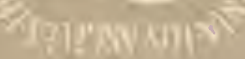

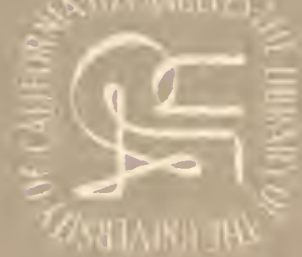

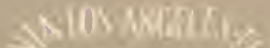

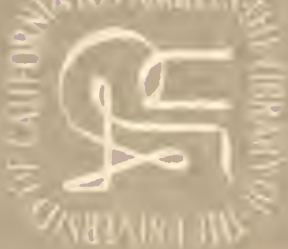

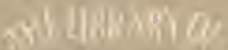

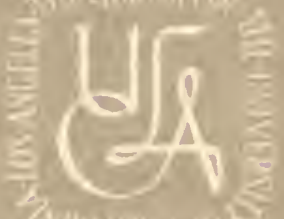

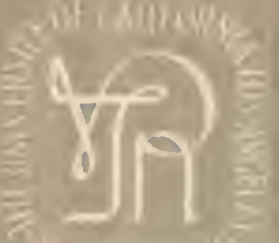

90.

ant INIVIIING

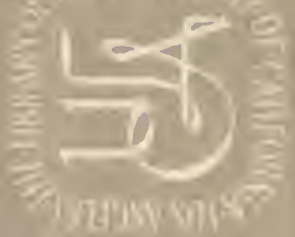

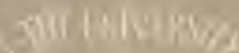

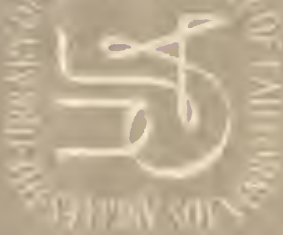

silstalionso

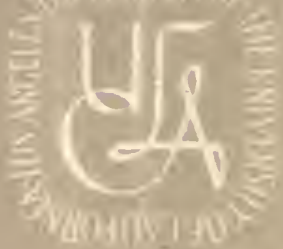

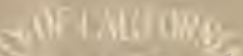

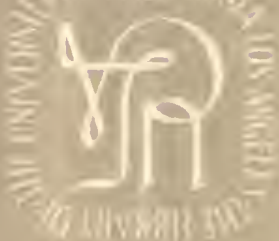

atilinainos.

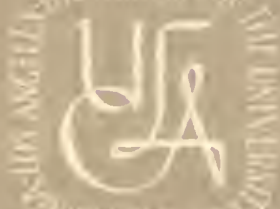

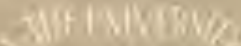

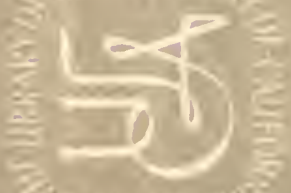


Digitized by the Internet Archive in 2007 with funding from Microsoft Corporation 



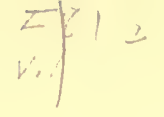

AUTHOR'S EDITION.

EXTRACTED FROM

\title{
a Consideration of SUME Ornithological Litera'ture, with EXTracts from CURrener CRiticism.
}

\section{1876 TO 1883 . II. 1884 IO 1893.}

\author{
BY L. S. Foster.
}

\section{6 to 1883 .}

Under the heading, "Recent Literature," in the volumes of the Bulletin of the Nuttall Ornithological Club, published from 1876 to 1883 , are review's of numerous publications which, I hold, pretty fairly represent the ornithological literature of this important period, particularly so far as North America is concerned.

A hasty survey of this literature might, perchance, convey the idea of individual effort rather than combined exertion, but, summarized, it shows an advanced movement along a series of lines which, at the close of the period, interlaced and formed the firm foundation upon which has been erected the solid superstructure of The American Ornithologists' Union.

The more prominent features of the time and those which will permanently characterize it, seem to be as follows :

The appearance of the first volume of the Catalogue of the Birds in the British Museum;

The revisionary work of Mr. Ridgway and Dr. Stejneger on certain orders and genera ;

The organization of The Linnean Society of New York, together with the publication of the first volume of its Transactions ; 
The publication of Biologra Centrali-Americant ;

The appearance of Mr. (ieorge N. Latwrence's "General Cittalogne of the Birds noted from the Islands of the lesser Antilles": Stearns and Coues's "New lingland Bird L.ife"; 1). Merrian's "Review of the Birds of Connecticut"; Dr. Wheaton's " Report on the Birds of (Ohio"; Dr. Cones's serice of four bibliographical papers and his check-list of $1 \$ \$ 2 ;$ Mr. Riderway's nomenclature of 1881 ; and the beginning of John Burroughes charming series of out-ofdoor books with the republication of "Watke-Robin" in 1877 .

In clearing the way for the A. (). U. check-list, the work on nomenclature which wis done by Mr. Ridgway and Dr. Stejneger was not only necessary but eminently workmanlike. In these featrs, the battle for trinomialism in North Americal was fought and gallintly won.

Especially will this period be notable as the epoch in which serious work wats begun in recording facts of migration: the Germans, the English, and, in this country, I'rof. II'. IV. Cooke, accomplished much.

[The continution of this paper, as read, consisted of mumerous examples of the criticisms which follow :]

\section{TIISR ANI CRITIRIS OF}

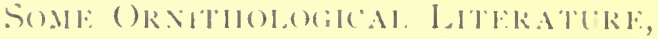

I.

$18-6,101823$.

$1 \times 76$.

Cooper, J. G. - New Futs relating to Californinn Ornithologr. No. 1. By Dr. J. G Cooper. P'roc. ('al. Acal. sci.. 1876. 14 pages.

...About fifty speeles nre noticel... The paper is replete with intersing matter, and forms a valuable contribution to onr knowledge

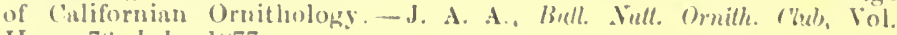
II., y $7 t i$, Inly, IsiT. 
D'Hanoxvmue, J. C. L. 'T'.-Catalogue des Oiseanx l'Europe, on énumération des espèces et races d'oisenux dont la présence, soit habituelle soit fortuite, a eté dîment constatée dans les limites géographiques de l'Enrope, par J. C. L. 'T. D'Hamonville. 8vo., pp. 74. Paris, 1876.

....deserves more than a mere mention on aceount of the admirably comprehensive manner in which it has been prepured. the Baron makes the whole nmmber $655, \ldots .$. - T. II. B., Bult. Nutt. Ornith. Clul, Vol. II., pp. 106, 107, October, 1877.

Gannod, A. H. - On some Anatomical Characters which bear mon the Major Divisions of the Passerine Birts. By A. H. Garrol. Proc. Zoöl. Soc. London, 1876.

....He conchiles his paper with a tabular arrangement of the larger gronps of the Passeres, expressive of his views of their affinities. -J. A. A., Bult. Nitl. Ornith. Club. Vol. II., p. 2'3, January, Is77.

Guxtry, 'Thomas G.--Life-Histories of the Birds of Eastern Pennsylvania. By Thomas G. Gentry. (In two volumes.) Vol. I: Philadelphia, 1876. 12 mo., pp. xvi., 309.

.... a most welcome volume of biographies of the birds of Eastern North America ... The author's style is unostentatious and simple, ut times lapsing into carelessness ... The present volume inchudes the Song-birds as far th the Corvide of Dr. Cones's arrangement ...J. A. A., Bull. Netl. Ornith. Club, Vol. I., pp. 49, 50, July, 1876.

Hexshaw, H. W.-Annual Report upon the Geographical Surveys West of the One-Hundredth Meridian, etc. By George M. Wheeler, First Lientenant of Engineers, U. S. A. Being Appendix J J of the Aunual Report of the Chief of Engineers for 1876. Washington: Government Priuting Oflice, 1876. Report on the Ornithology of the Portions of California visited during the Field Season of 1875. By Mr. H. W. Henshisw. Pp. 224-278.

....Among the more important results are the extension, either sonthward or westwarl, of the previously recorded runge of mauy species of birds ...'The biographical annotations are often finli and always exceedingly interesting ...-W. B., Ball. Nult. Ornilh. Clel,, Vol. III., pp. 136, 137, July, 1878 .

Jordan, David Starr. - Manual of the Vertebrates of the Northeru United States, including the District east of the Mississippi River, and north of North Carolina and Tennessee, exclnsive of Marine Species. By David Starr Jordan, M.S., M.D., etc. Chicago, 1876. 12mo., pp. 342.

.... Several of the analitical tables of different groups of birds are based on or taken directly trom Cones's liey, and the latest and best atuthorities are followed for the other classes ... On the whole the anthor is to be congratulated on the success he has achiever in this difficult undertaking, combining in a work of convenient size and moderate 
eost $n$ text-bonk of the Vertubrat. Animals of the Northenstern States relinble in churueter nnel suffleidntly extended to guid. the student with

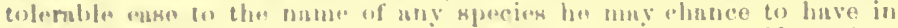

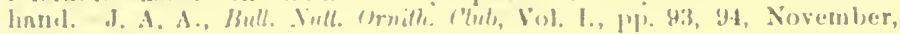
1876.

Kimser, J. H.-- Contributions to the Nitural Ilistory of Kerguelen

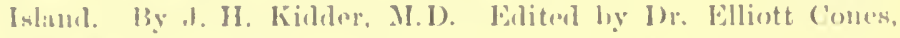

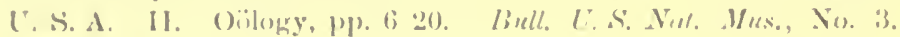
Wushington, 147t;.

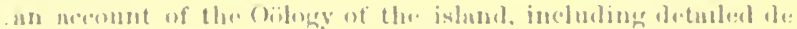

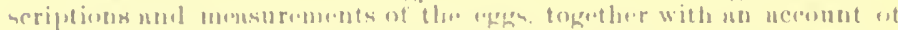

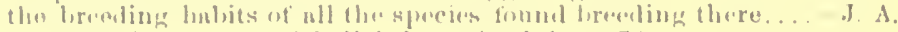

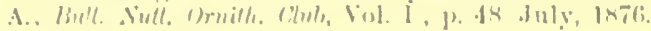

limbra, I. H. - Contributions to the Natural History of Kerguelen

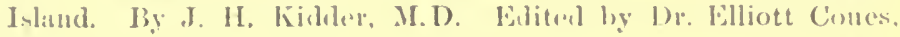

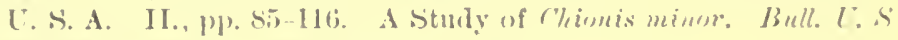
Nit. Mus., No. 3. Wushingtou, 1876.

This e-say opens with a rismme of the litoruture of the surecics 'J'hen follows a deseription of itw nnatoms, including un ucesont of its myolog!s of the viscera and the skeleton; of its habits. feneral appestance in life, and external charncters..... J. A. A., Pull. Sill. Unill. (7wh, lol I., pp. 48, 4!), July, 1siti.

Lawhexce, Georae N. - Deseription of a New Species of Jay of the Genus Cyanocitta; also of usnpposed New Species of Cymororix. By George $\mathrm{D}$. Lawlenee. Anmuls of the Lyceum uf Vut. Mist. V. Y., Vol. XI., pp. 163-16in. [P'ulblished Fel,., Isiti.]

....(Cyamecilta pulchme) being from Ecuador and the other ('yame-

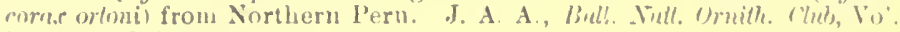
1., p. 47, J11!, $187 i$.

Iawnesce, Gronge N. - Birds of Sonthwestern Mexico collected by Francis E. Sumichrast. P'repared hy Grorge N. Lawrence. liull. I. s. Nat. Wus., No. t. Waslington, 1Siti.

Thu list embrnces three hundred und twonty-one species, with valuable and ocessionally quite copions firhl-notes liy the eollector

J. A. A., Bull. Vull. Orith. Eivd, bol. I., p. 93, November, 1876.

Mansu, O. C. - Extinct Birds with T'ereth. By l'rofessor O. C. Marsh. Am. Jour. Sci. and .1\%s, June, 1sit, pl). 509-511.

'Tlyese interesting forms ...e eombinw in a peculinr manner many reptilian characters with others truly avian. J. A. A.. Bull. Vutt. Ornith. ('lul), V(o). I., 1., 4!), Inly, 1×iti.

Rmawar, limbar. - Serond Thomghts on the Genus Micrastur. By Robort kidgway. The lhis, 1876, pl. 15.

Runiw. Ronent. - Studies of the American Fulconidit : Monograph 
of the Polybori. By Robert Ridgway. Bull. U. S. Geol. rind Geogr. Surv. of Terr., Vol. I., No.6, pp. 451-473, plates xxii.xxvii., February 8, 1876.

Ridgway, Roben'r. - Studies of the American Falconidae. By Robert Ridgway. Bull. U. S. Geol. and Geogr. Surv. of Terr., Vol. II., No. 2, pp. 91-182, plates xxxi., xxxii., April 1, 1876.

Saunders, Howalid.-On the Stercorariine or Skua Gulls. By Howard Saunders, F.L.S. \&e. Proc. Zoöl. Soc. London, 1876, pl.317-332, pl. xxiv.

Mr. Saunders recognizes six species, all of which he refers to one genus for which he adopts the name Stercorarius....-J. A. A., Bull. Nutt. Ornith. Cheb, Vol. IL., pp. '23, 24, January, 1877.

Saunders, Howanw, - On the Sternine, or 'T'erns, with Descriptions of three new Species. By Howard Saunders, F.L.S., F.Z.S. Proc. Zoöl. Soc. Iondon, 1876, pp. 688-672, pl. lxi.

. Of the forty-eight species recognized, thirty-eight are placed under S errr....-J. A. A., Bull. Nutt. Ornith. Clnb, Vol. II., p. 24, January, 1877.

.... We have here in condensed and convenient sliape the main results of a protracted study, representing much laborious and faithful application; the author has evidently worked with care, and fully avaled himself of the unusual facilities he has enjoyed.... I regard the paper as the most anthoritative one we possess on this subject. ....'The colored plate illustrates the heads of three species of Anous ... -Elliott Coues, Bull Nut. Ornith. Club, Vol. III., pp. 140-144, July, 1878.

Sclatel, P. L. and Salvin, OsBeit, - On new Species of Bolivian Birds. By P. L. Sclater, M.A., Ph.D., F.R.S., 'and Osbert Salvin, M.A., F.R.S. Proc. Zoül. Soc. London, 1876, pp. 352-358, pll. xxxxxxiii.

Sclater, P. L. and Salvin, Osbert.-Revision of the Neotropical Anatidie. By P. L. Sclater and O. Salvin. Proc. Zoül. Soc. London, 1876, pp. 358-412, pl. xxxiv.

... a most valuable synopsis of the Ducks and Geese of Middle and Southern America, and embraces also a large proportion of the species of North America, including as it does all that reach Tropical America in their migrations.. The paper closes with a very convenient tabular synopsis of the geographical distribution of the genera and species. - J. A. A., Bull. Nilt. Ornith. Club, Vol. Il., p. 24, January, 1877.

Vensor, Hexry G.-Our Birds of Prey; or the Eagles, Hawks, and Owls of Canada. By Henry G. Vemmor, F.G.S. Of the Geologieal Survey of Cunala. With 30 Photographic Illustrations by Wm. Notman. Montreal: Published by Dawson Brothers. 1876. 4to., pp. i-viii and 1-154, 30 mounted photographs of birds.

....The text, which is largely compiled from the notes of other 
writurs, fives a tanrly digested smmmury of the andivilunl history of mele npincies

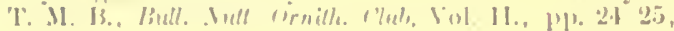

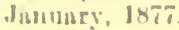

\section{8.}

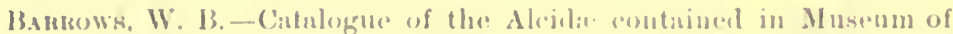
the Buston Socinty of Sintural History, with n review and proposed clussiticution of the l'umily. By W. B. Barrows. P'roc. Broston s'se.

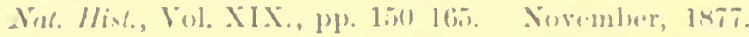

...The true utlinities of the species les Mr. Burrows heliepes can only be determinem by athorough stuly of their conbryologieal development. The eluneter of this paper indientes that is Mr. finrows we

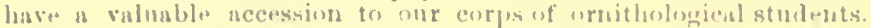

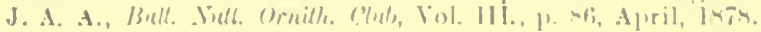

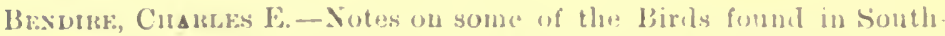
enstern (Oregen, purticularly in the Vicinity of (ampl litrueg, from November, 187t, to .umury, 1s7\%. By Ciultain C'harles bendire,

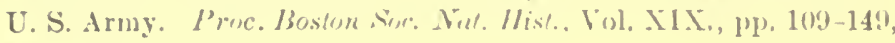
Nov., $157 \%$.

... a list eubracing one bundred and ninetyour species and varieties .. Aside frum some former notes by the sume anthor... we have here onr first letuiled information respecting the ornithology of the immediute region under consilerution. The list is enriched with copious biogmplisen notes, indmatug descruptions of the breeling. halits, nests, mal eggs of a large mumber of the less well-known splecies.

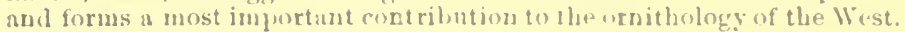

J. A. A., Bisll. Vult. Ornith C(ul, Vol. III, 1. At, April, isix.

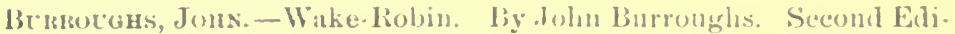
tion, corrected, enlaged und illustratel (cut). Now York: Published by Hurd and Houghton. Cambrilge: The liversirle I'ress, 1s77, $16 \mathrm{mo.}$ 1). 1 2.56, frontispicece nul wuol cuts.

Hurd nnd Houghton have reprinted Mr. John Burronghs's charm. ing little volume "Wake. Robin." whereln the will woul-life of the birds, from Washington to the Adironduchs is pieturestpely sketched.

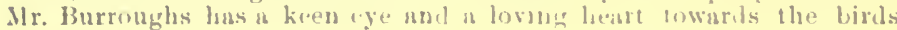

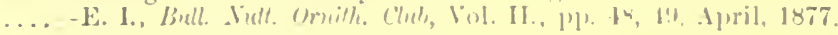

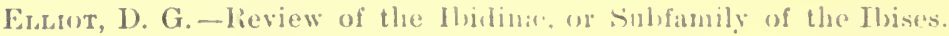

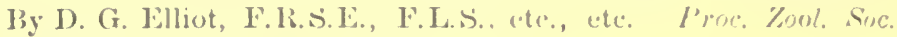
Iondon, 1877, ply. 477 j10, pl. li.

Mr. Flliot treats the Hlises und spoubluls ats subfanilies of

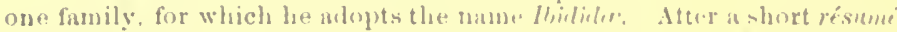
of the liturature of tiue subject her gives a ker to the ninetcen genera (there being new), among whah he listributen his twenty-tive -precions Then follows a systemati review of the species, with their principal

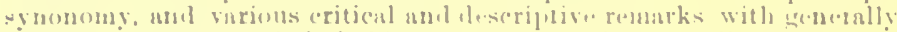
a short areonrt of their halits and gengraplical distrihution...

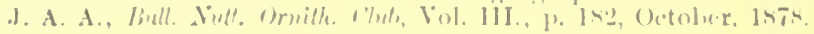


Feilden, H. W. - List of Birds observed in Smith Sound, and in the Polar Basin dnring the Arctic Expedition of 1875-76. By H. W. Feildcn. The lbis, Fomrth Series, Vol. I., pp. 401-412, October, 1877.

....enumerates twenty-four species observed...." in Smith Sound and northward between the seventy-eighth and eighty-third degrees of north latitude,"....The wnite detailed notes respecting the species of this list render it a paper of unmsual interest. -J. A. A., Bull. Nutt. Orvith. Clul, Vol. III., p. 86, A pril, 1878.

Gentry, Thomas G.-Life-Histories of the Birls of Eastern Pennsylvania. By Thomas G. Gentry. Vol. II., 8vo., pp. 336. The Natmralist's Agency, Salem, Mass., 1877.

.... It abonnds in original observations, combined with tnuch that is gleaned from other anthors.... Despite some faults of execution, the work before us contributes much of value respecting the habits of onr birds, and records many interesting noints in their history not given by previous writers.--J. A. A., Bull. Nutt. Ornith. Chu, Vol. III., pp. 36,37, January, 1878.

H.hve Brows, J. A.-On the Distribntion of Birds in North Rnssia. Part I. On the Distribntion of Birds of the Lower Petchora, in Northeast Rnssia. Part II. Longitudinal Distribution of Species North of $64^{\circ} 30^{\prime} \mathrm{N}$. lat., or the Northern Division. Part III. On the Longitudinal Distribution of the Birds of the Sonthern Division (between $64 \frac{1}{2^{\circ}}$ N. and $58^{\circ}-60^{\circ}$ N.). By J. A. HarvieBrown. Annals and Magazine of Natural History, April, July, and September, 1877.

By means of a system of symbols the range of each of the two lunndred and eighty-one positively identified or anthentic species is given in tables, in such a way as to indicate the abundance or scarcity of the species in each of the several districts ...It is good work in a most important direction ... The number of circumpolar species inearly fifty) embraced in these list. render these papers of special interest to students who commonly confine their attention to the birds of the North American Region.--J. A. A., Bull. Nutt. Urnith. Club, Vol. III, pp. 35,36 , Jannary, 1878.

Henshaw, H. W.-Anuual Report upon the Geographical Surveys West of the One-Hundredth Meridian, etc. By George M. Wheeler, First Lientenant of Engineers, U. S. A. Being Appendix N N of the Annnal Report of Engineers for 1877. Washington: Goverument Printing-Office, 1877. Report on the Ornithology of Portions of Nevala and California. By Mr. H. W. Henshaw. Pp. 1303-1322.

....following is a srstematic and very able consideration of the fannal provinces of the Tnited States... The full results of the season's work are given in two detailed lists, entitled, respectively, "List of Birds observed near Carson City, Nevada, from August 25 to Septem. her 16, and from November 10 to November 20, 1876, with Notes," 


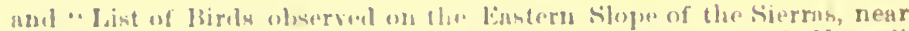

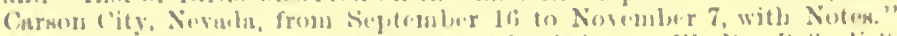

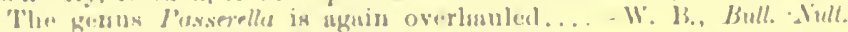
(truth. Clul, Vul. III, J[. 137, 138, July, 1878.

Liscinos, Fins W. - A (intulegue of the Birds of the vicinity of ('incinuati, with Notes. liy Frank II. Iangelons. Sulem, Mass. 'The Nuturuliat's Igetucy, 1877, 8vo., pp. 18.

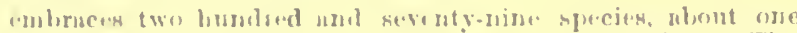
third of which are murkml uk known to hroed in the vicinity... 'Ilıe list is eviclently prepured with cara. und gives u eorvenient and mudombteliy trustworthy sum mary of the Avinn Fum of the lovalits of

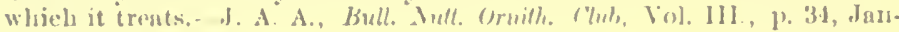
nary, $18 \% 8$.

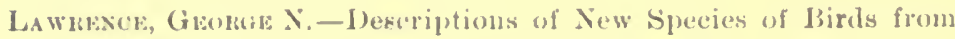
the Islsud of I lominian. By George X. Lawronee. Ans. N. Y. Acal. sci., Vol. I., pI). 46-19. 1ssued Dec., 1877.

Tle insunrtant explorations by Mr. F. A. Olier in some of the

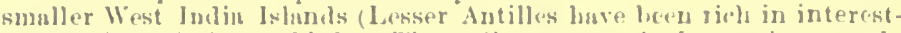
ing results reluting to bircls. 'T'ls, collections and olservations nude ly Mr. ()ber lave been male: the husis ot several rectut papers by Mr. fienrge 5 Iawresce, in which no less than fourto "Is specius supjosed to be new have bern deseribed .J. A. A., linll. Iutt. Urnith. Chub, Vol. IV., pl). 46, 4!, Jaunary, 1874.

McCarley, C. A. H.-Notes on the Oruithology of the Region about the Source of the lied liver of 'lexas, from Oloservations made during the Exploration conducted hy Licntenant E. H. Rufiner, Corjes of Engmeers, U. S. A. Ry. C. A. II. MeCanley, Lientenant 'Third Cuiterl States Artillery. Aunotatol hy Dr. Ellott Cones,

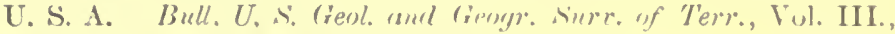
No. 3, P1) 655-645, May 15, 1577.

.. The paper includes notices of al ont one hundred species, with quite copions notes reppecting the habits of in consielernble proportion of them, with, in some cases, deseriptions of the'ir nests and extrs...

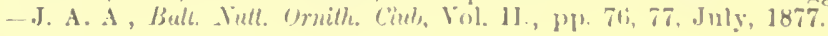

Memian, C. Hakr - A review of the liirls of Connecticut, with liemnrks on their Halits. Jiy ('. Hart Merrian. Trans. Conn. Acul. of Arets aml siciences, Vol. IV., ply. 1-151), July-Oct., 167T.

... Since the appenrunee of Liusley's "Catulogue of the Birds of Connecticut" in 1843, no detailed crmmeration of the birds of that state lus been published. Hence the adsent of Mr. Arrrinus puer must 1.. hailen with interest by all angaged in the study of New Fngland ()mithology. The antlar gives in all tho bumlred and ninety-two species. In the carrful eluborution of interesting details culled frou personal experionee and the note-books of well-known and trustworthy

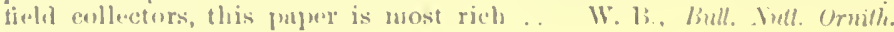
(\%), Vol. II., 1\%). 107, lus, Uctober, 187T. 
Minot, H. D.-The Land-birds and Game-birds of New England, with descriptions of the birds, their nests and eggs, their habits and notes. With illustrations. By H. D. Minot.

"To him who in the love of Nature holds

"Communion with her visible lorms, she speaks

"A vurious language:"

Bryaut's 'Thatuatopsis.

Salem, Mass. Naturalists' Agency. Boston: Listes d Lanriat. 1877. 8vo,, pp. i-xvi and 1-456, frontispiece and woodents.

...the descriptions, however, are tersely original... the most prominent and most original features of the work are the artificial "keys."...-E. C., Bull. Nutt. Ornith. Club, Vol. II., pp. 49, 50, April, 1877 .

. the book has never been reviewed on its merits, and things which shonld have been severely censured have passed nearly nnchal. lenged $u p$ to the present time .. leaving out the fanlty portions, which in nearly all cases relate to abstract points similar to those just citer [careless methods of work and identinication], the pages bear the impress of accurate observation and original thonght, while no one who loves the ont-door sile of Nuture can fail to sympathize with the antbor's sentiment or to be impressed by the truth and beanty of nany ot his passages It is a pity that one who writes so delightfully will mar his work by a persistent adbesion to false principles. - William Brewster, Bull. Nult. Ornith. Cluh, Vol. VI., pp. 242-244, October, $18 \triangleleft 1$.

Nirson, E. W.-Birds of Northeastern Illinois. By E. W. Nelson. Bull. Essex Inst., Vol. VIII., pp. 90-155, April, 1877.

It is not, however, from the simple enumeration of species that this list derives its chief value and interest, but from the unusually complete and satisfactory character of the biographical annotations, which embrace good descriptions of the habits of many birds previously hat little known ....--IV. B., Bull. Nutt. Ornith. Chub, Vol. It., pp. 68, 69 , July, 1877.

Necson, E. W.-Notes npon Birds observed in Southern Illinois, between July 17 and September 4, 1875. By E. W. Nelson. Bull. Essex Inst., Vol. IX., pp. 32-65, June, 1877.

...contains much information respecting the distribution, habits, and relative abundance of the sumimer birds of the southern portion of the ...State....-J. A. A., Bull. Nitt. Ornith. (lul, Vol. III., p. 36, Janunry, 1878 .

Rathbun, Frani R.-A Partial Catalogne of the Birds of Central New York, from observations taken in the Connties of Caynga, Seneca, and Wayne by Mr. H. G. Fowler, of Auburn, N. Y., and from the Cabinet of Skins of New York Birds collected by Mr. J. B. Gilbert, of Penn Yan, Yates County. Divided and arranged in accordance with the "Check List of North American Birds," hy Elliott Coues, M.D., U.S. A., am dedieated to the Caynga Historical Society. By Frank J3. Rathbun. Auburn Daily id vertiser (newspaper) of August 14, 1877.

.... The list contaias one hundred and ninety-one species, with brief notes on their relative abundance, times of wigration, etc. The 
liat beser esilenere of trustworthiness J. A. A., Bull. Jiull. Ormith.

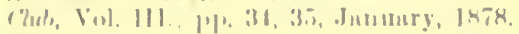

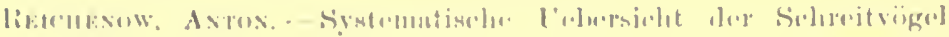

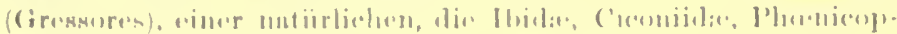

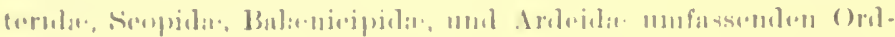

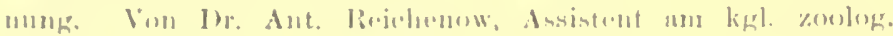

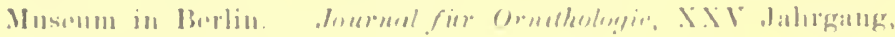
l'l. I1:3 171, 202, 27x, pll. i, ii. April and Inly, I87.

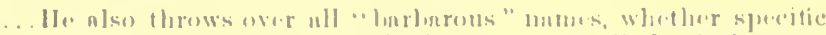

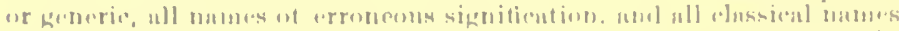

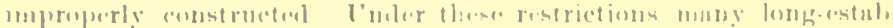

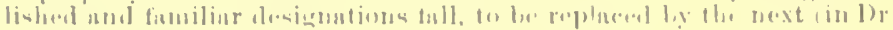

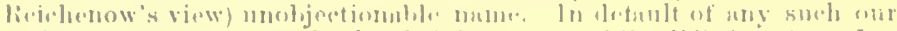

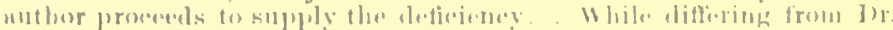

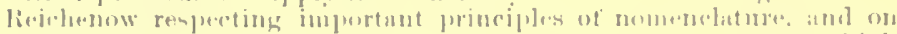

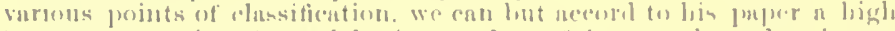

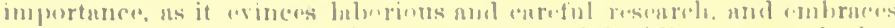

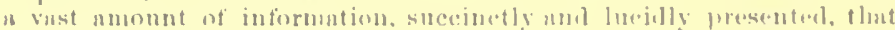
will le of Lreat service to tuture worlices un the sume tifele. J. A. A.

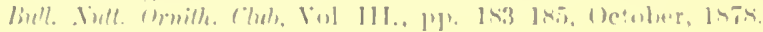

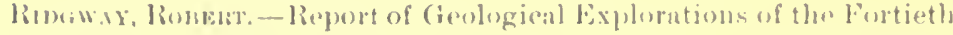
larullol. ('lauence lingr. Goologist in Clange". Vinl. IV., l'art

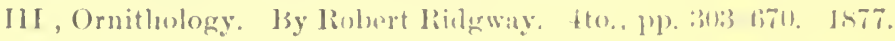

...n thoromgh nud exhnustise aceomnt of the oruthology of an interesting belt of eomntr. Jhe olsersutions were mainly limited to that portion of the (irest jissun inclublel luetwe+n the thirty-uinth and forty-secont purallele nut extending from the sierra levalo to the Wubstoh Mountains. in loint of someneluture it represt uts the

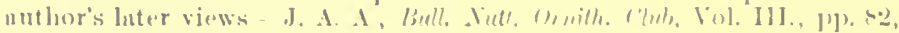
ris April, ISTir.

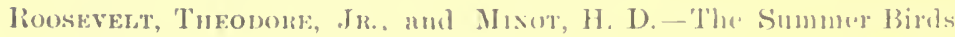
of the Arirondacks in Franklin ('onuty. X. I. By 'Tlesube

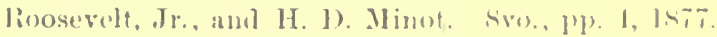

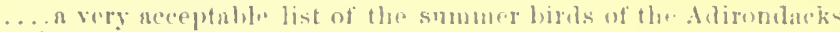

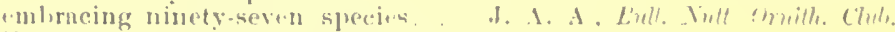

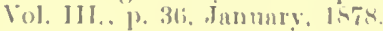

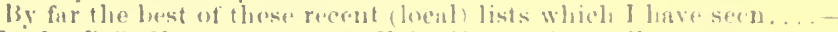

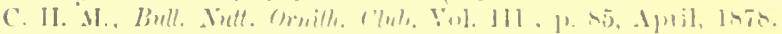

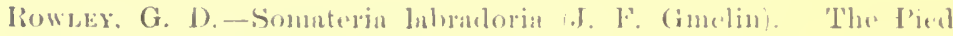

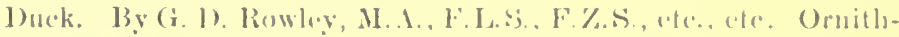

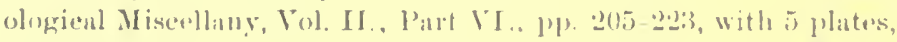

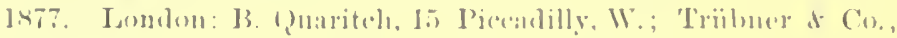

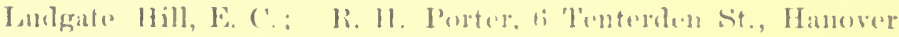
Sijuare, IV.

. . a timely nul exlumstive antrihution totle history of a species

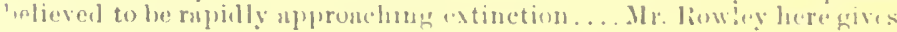


not only the literary history of the species, but discusses its relationship, to the Eiders ...-J. A. A., Bull. Null. Ornith. ('tut), Vol. IlI., pp. 79, 80 , April, 1878.

Salvin, Osisert. --Salvin on the Procellaridae. Rowley's Ornithological Miscellany. Part IV. London, 1887.

... 'lhis paper is in two parts. 'The first is devoted to an examination of the unpublished "Banks' drawings," und the munuscripts of 1)r. Solander, so tinr as they relate to the P'etrels ....MIr. Sialvin's second paper is a carctul exumiuation of the new species of Petrels olitrined by Dr. II. H. Giglioli during the voynge of the Italinn eorvette "Magenta" rome the world...... T. II. I;, Bu'l. Nut. Irnith C'lub, Vol. II., pp. 69), 70, July, 1877 .

Suane, 1i. Jowdenk. - Catalogne of the Birls of the British Museum.

Vol. III. Catalogne of the Coliomorplue, containing the families Corvidar, Paradiseidae, Oriolida, Dicrurida, and Prionopida. By R. Bowdler Sharpe, 8vo, pp, xiii., 344, pll, xiv. 1877.

In the third volume Mr. Sharpe enters mpon the great series of Passerine Birils The speries here described by Mr. Shmrpe number three hundrel and sixtr-seven... We are sorry to see several instances ot the use of the same name in a generic and specific sense for the same species....J.J. A. A., Bull. Vutt. Ornith. Club, Vol. III., Pp. 78, 79, April, 1878.

Streets, Tironas H.-Contributions to the Natural History of the Hawaijan and Fanning Islauds and Lower California, made in counection with the United States North Pacific Surveying Expedition, 1873-75. By Thos. H. Streets, M.D., Passed Assistant Surgeon, U. s. Navy. Bull. U. S. N u. Mus., No. 7, 8vo., (Birds, pp. 9-33), Washingtou, 1877.

... includes notes on abont tifty species of birds, of which rather more than one-halt' were collected on the const of Lower California and adjoining portious of the Mexican coast. The anthor acknowledges his indebtedness to Dr. Elliott Cones. U. S. A., for the identifiention of the birds, and adds that he hus "kindly furnished the notes accompanying that portion of the ornithological collection from the Californian Peniusula $" .$. there are many valuable biographical and other notes on sereral hitherto little known species.-J. A. A., Bull. Nitt. (hrith Cull, Vol. III., pp. 8v, 81, A pril, 1878.

Willa1w, S. L.-A List of the Birds of Ceutral New York. Utica, N. Y, 1877. By S. L. Willard, Esq. 16 pp.

The anthor's remarks in the way of a prelude are thus brietly expressed : "The following is a complete list of the birds of Central New York, with notes on their abundance." This might lead one to expect a valuable contribution to our science, but a perusal of the "List" proves this supposition to be erroneous....-C. H. MI., Bull. Tuti.

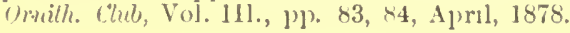




\section{ISTX.}

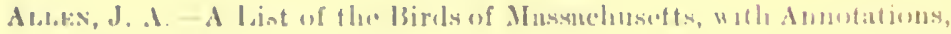

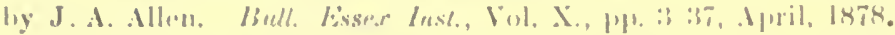

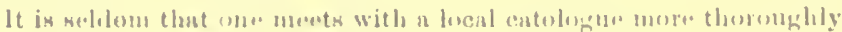
matisfactory in all essental resperts than the present on" . this list

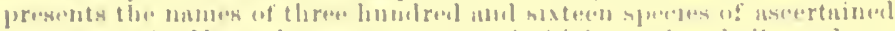

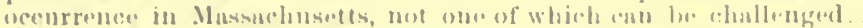

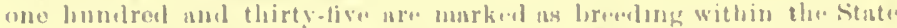

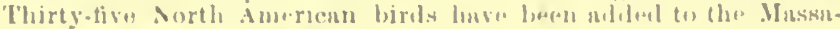

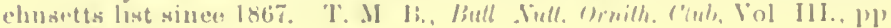
134-110, July, 1878 .

Aloner, simek1. - Notes on the Nature of the Feorl of the Birls of Coloraska. By l'rofessur Simmul Aughey, of Limeolu, Nob.

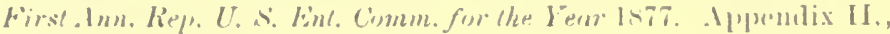
up $1362.187 \mathrm{~A}$.

....The list numbers two humled and tifty specis, and henm. includes a pretfy large proportion of the birds that visit the state, and ns the list relates ostensibly to only locust-catmog specirs, our titat forel. ing is one of surprise that it should the so lares Although .Ir.

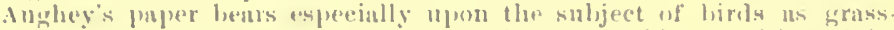
hopper destrovers, it forms at the some timen vulushle. faumbl list of the birils of Soutian Nebraska, contuining notes relatiug to the relatiw.

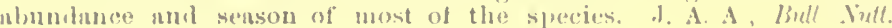

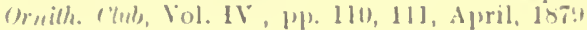

Alouter, Sambis. - Some facts and considerations concerning the beneficial work of hirls. By Professor Samuel Angley, of lin-

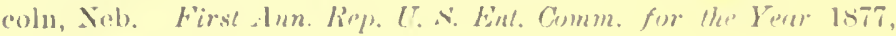
pls. $3334.330,1878$.

... A special communicution on the general sulject of the nseful. ness of birils. with particular regard. hewever. to the locenst puestion ....lue coneludes that even the majority of liapterial birds slondel the protected ...He believes that sooner wr hater the protection of nastat birks shonlil beeome not only a mational. bat an international matter.

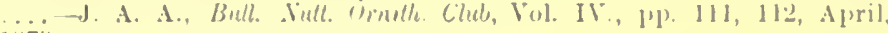
1879 .

Bkwwer, T. M.-Notes on certain Sprecies of New England Birds, with Arlditions to his Catalogre of the birds of Now England.

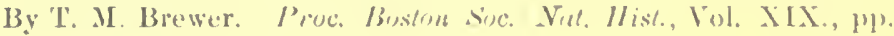
:301-309, April, 1878.

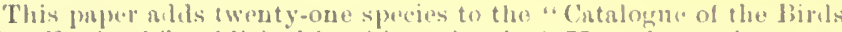
of Now England," published by this author in 1s75, ard contuins uoter

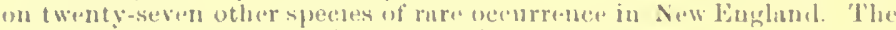
whole number of "reengniaed forms " now mbitted hy him as laving

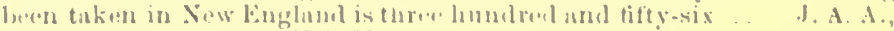

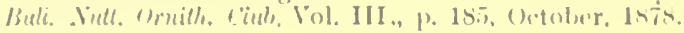

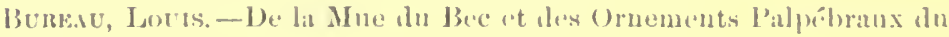


Macareux arctique, Fratercula aretica (Lin.) Stepl., après la saison des amours. Par le Docteur Lonis Burean. Lictrait alu Bulletin "le la Société Znologique de Frrence, 1877. 8vo. Paris, 1878. P'P. 1-21, pll. iv., v.

The remarknble changes which the bill aud eyelisls of the Common Puffin undergo after the breeding season have been hitherto unkuown 'lhe author's exposition of the matter reveas a phenomenon us yet unparalleled among birds The unthor concludes this remarkable paper with some pertinent and suggestive observations on other species if Fratercula und on Lundit cirrheltu. - Elliott Cones, Buil. Nult. Ormill. Club, Vol. III., 112. 87-91, April 1878.

Cory, Charles B.-A Naturulist in the Magdaleu Islands; giving a Description of the Islands, and List of the Birds taken there, with other Ornithological Notes. By Charles B. Cory. Illustrated from Sketehes by the Author. Boston, 1878. Small 4to. Part II., Cataiogue of Birds taken or observed in the Magdalen Islands, with Notes regarding those found breeding, etc., etc. Pp. 33-83.

In a sumptuons little quarto Mr. C. B. Cory has given an account of a summer trip to the Magdalen Islands in the Gulf of St. Lawrence. ....Part I. consists of $n$ general account of the Islands . and directions how to reach the Iagdalen group, etc. Part II. gives a list of one hundred and nine species observed and taken by the author .

The annotations relate mainly to the habits and relative abunilunce of the species ...-J. A. A., Bull. Nult. Ornith. Club, Vol. IV., p. 171, July, 1879 .

Codes, Elciotr-Birds of the Colorado Valley. A Repository of Scicntific and Popnlar Information concerning North American Ornithology. By Elliott Cones. Part First. Passeres to Laniida. Bibliographical Appendix. Seventy illustrations (woodeuts). 8vo. Pp. xvi., S07. Washington: Government Printing Office, 1878. "Miscellaneons Publications, No. 11," of the United States Geological Survey of the Territories, F. V. Hayden, U. S. Geologist-in-Charge.

In point of completeness, mode of execution, and general usefulness, the bibliography here under notice far excels any natural history libliography known to us, aud deserves to rank with the best bibliographies of any department of literature, and may well serve as a model for future workers in similar fields....As regards the general work, or the "Birds of the C'oloralo Valley" as a whole, no more ituportant contribution to the subject of North American Oraithology than this promises to be has for a long time appeared, anil none covering all points of the field lhere taken;....-J. A. A.. IBull. Nitt. Ornill. Club, Vol. IV., pp. 54-57, January, 1879.

Coues, Eumotr. - Field Notes on Birds observed in Dakota and Montana along the Forty-ninth Parallel during the Seasons of 1873 and 1874. By Dr. Elliott Cones, U. S. A., late Surgeon and Naturalist 


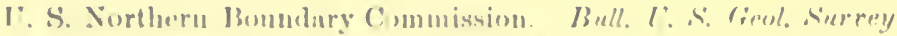

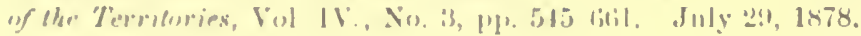

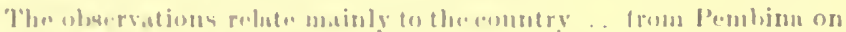

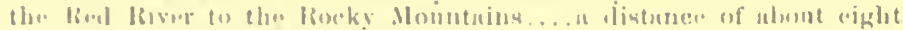

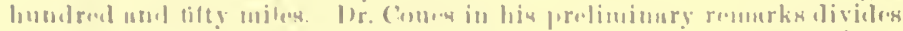
tlat (2)

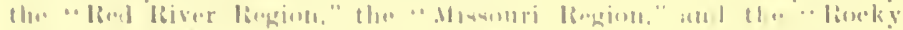

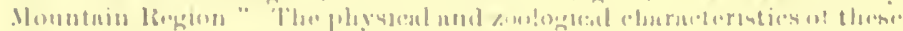

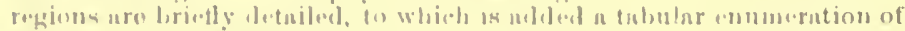

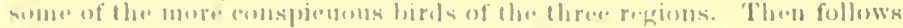

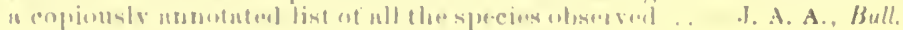

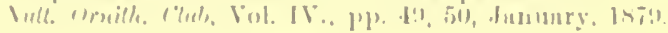

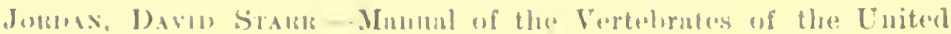
Stutes, iuchuling the District mat of the Mississippi liver, mut

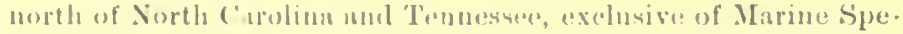

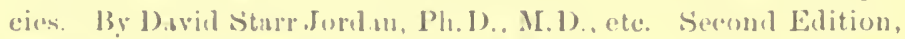
reviserl and enlargerl. Chionges: Meclorg a Co., 18is. 12mo., (1). 407 .

...the second edition has not only been to some extent "revised,"

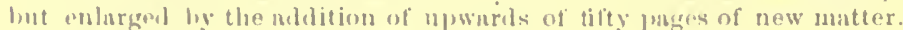

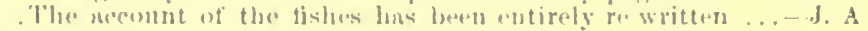

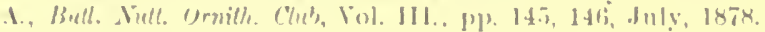

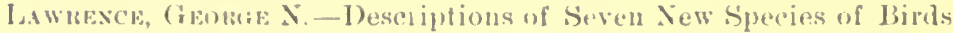
from the Island of St. Vincent, West Indirs. Wy (ieorge N. Latw-

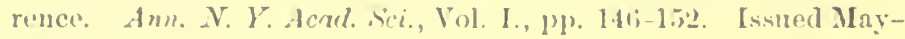
Suptumber, 1sis.

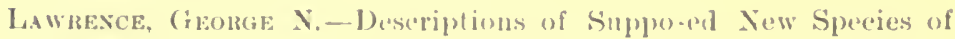
Birds from the Islands of (iremula and Inominica, West Indies. liy cieorge X. Jawrenees. Alu, I. Y. Acrul. Sei., Vol. I., pp. 160-11i3. Issued Muy-September, 18:8.

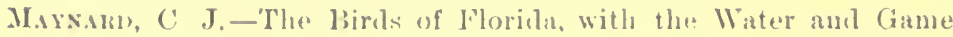
Birds of Eastern North Amerien. Ly ('. J Misumri. Illustrated. 4to. I'urt IV., pp. s! -112, mel ume J'ate. C. J. Mayuard s Co., Newtomville. Mass, 18,

is wholly devoted to the fumily Frimpillifer. of which fourtern species are described .. It is illustrated with $n$ tine coloreal plate of the I pswiels or Pnllid sparrow (Passerendes princess, representing the alult in spring. 'Io originnl, somewlut detailed destriptious of the different

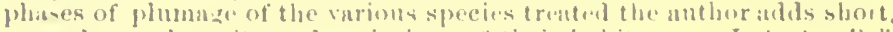
very plemsantly written deseriptions of their hatsits. J. A. A., Buell.

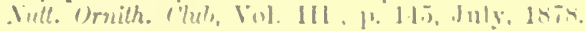

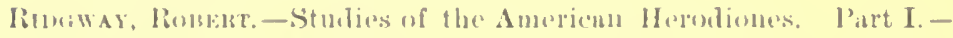

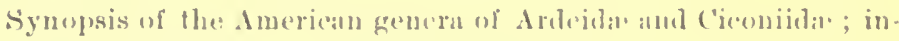
cluding descriptions of three new genera, and a monegraple of the 
American species of the genus Arlea. By Robert Ridgway. Bull. U. S. Geol. and Geogr. Surv. of 'Terr., Vol. IV., pp. 219-251, February 5, 1878.

The first of a series of papers here hegun deals mainly witl tho Ardrides and Ciconiide. ...'The 1. wimlemanni of Baird, which has been a puzale to ornithologists for twenty years is consilere- to be the "blne phase" of A. Orcidentulis' . J. A. A., Bull. Ault. Ornith. Club, Vol. III., 1'p. 182, 183, October, 1878.

Saunders, Howan1).-On the Larinar. By Howard Sannders. Proc. Zoöl. Soc. London, 1878, pp. 115-212.

The whole number of species recognized in this paper is forty-nine, of which number twenty may be counted as North American ...Mr. Sannders's paper evinces " remarkuble success in disentaugling the complicated web of Enropean Gulls....and the service rendered by Mr. Saunders cannot finil to be appreciated by all who have experienceil its need.-C. M. 13., Bull. Vult. Irrith. Chib, Vol. II1., pp 185 InT, October, 1878.

Sennert, Geonge B.-Notes on the Ornithology of the Lower Rio Grande of Texas, from Observations malle during the Season of 1877. By George B. Sennett. Edited, with Aunotations, by Dr. Elliott Cones, U.S. A. Bull. U. S. Geol. and Geogr. Surv. of 'Terr., Vol, IV., pp. 1-66, February 5, 1878.

.... on one hundred and fifty-one species of birds observed on the sonthern border of Texas.....Mr. Sennett certininly collected under many annoyunces, but intensely hot days.... . did not prevent his securing some five hundred birds, one of wbich is new to scierice. ramely, Sennett's Warbler (Parula nigriora). 'The paper is most carefinlly commentated by Dr. Cones ...-H. A. P., Bull. Iitt. Urnith. Club, Vol. III., pp. 144, [45, Jnly, 1878.

Sterenson, H.-Adams's Notes on the Birds of Alaska. By H. Stevenson. The 1 bis, 4 th Series, Vol. II., pp. 420442 , Oct., 1878 ,

Some twenty-eight years ago (October, 1850) Mr. Edward Adams, a surgeon in the British navy ... was sent to the Redoubt of Michalaski. on the shores of Norton Sound, Alaska. He remained there mntil late in the following June, and made some very interestivg and valuable notes on the birds of the region. His collections were given to the British Musemm, to Mr. John Gould, and to the late Mr. G. R. (iriy. 'The latter dedicated to him the Colymbus adcursi .. These early observations of Alaskan species... have intrinsic interest and are well worthy of attention. - T. II. B., Buil. Sint. Urilh. Club, Vol. IV., pp. 52,53 , January, 1879.

Wirson, Alexander, and Bosaparte, Chamles Lucian.-American Ornithology ; or, The Natural History of the Birds of the United States. Illustrated witl plates evgraved from drawings from Niture. By Alexander Wilson and Charles Lucian Bonaparte. Popular edition. Philadelphia: Porter and Coates. Three volumes in one.

It claims to be an exact reprodnetion. minns the atlas of colored plates, of the $\$ 100$, three-volnme edition issued by the same lirm some 
yenrs «go. No one can help rojoicing at nny offort to disseminate more wilely an nepunintunce with Alexnmler Wilson and his charming und puinstaking work... Kut simply to roprint Wilson, "ven with Bonaparta mled. at s7 so, pointing ont none of the orrors. nor snpplementing thw shorteominges is, to sny the lasut, uttorly mune('essury to the al-

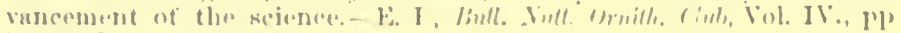
53,54, Juแนเy, 1879.

\section{9.}

Buranes, It.-A Partinl List of the Birls of Centrul Culifornin. By L. Belliug, of Storektorn. Ealited ly R. Rirlgway. P'roc. U. S.

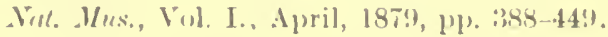

... It is hased... npon olsservations extending thromgh shout

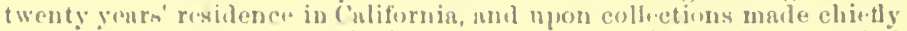
during the last two vears, which have from time to time, bee forwared by Mr. Belding to the National Nusenm T'he mumber of species. (xilusive of the waling und swimming birds, is lis . In respert to the designation of incipient species, Mr. lingway uniformly alopts the. syatem advotuted by lim in his puper on the use of trinomials in moilogienl nomenclature in the present number of the Bulletin.. As ulremly stuted. Mr. Ridgwny was the first to alupt the system of pure: trinominls, and we regret to note his divergence therefrom .... - J. A. А.,

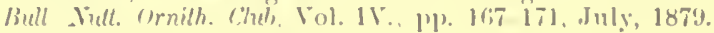

BמEwE⿺, 'T. M. -Some Aditional Notes npon birils observed in Nir lingland, with the Nanes of Five species not inclnded in his Previous Lists of New Engham Birds. By 'T. M. Brewer. Proc. Boston Soc. Nat. Mist., Vol. X.., 1p. 263-277. I'nhlisherl Deeemher, 1879 .

.... It forms a second supplement to his ". Cintulugne of the Birds of New England," published in 1875, und adds tive species to the number previously reengnizol by him us New England hiris, ruising the whole number to 361 . These "Notes" form 4 convenient and connceter record of recent liscoveries in relation io many of the rarer New Englami birks, and ald more or less thut is new respecting sonie of

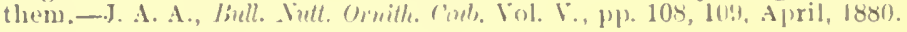

Coves, Eldiort. On the Present Statns of l'asser domeslicus in Americil, with Special IReference to the Western States aud 'Tarritories. By Dr. Elliott Comes, L. S. A. Bull. IT. S. Geul. and reogr. Surte of Terr., Vol. V., 1'1, 175-19:3, Sept. 19, 1879.

...a partial bibliography ot, what is commonly termed the "Spnrrow-War in Am+rica" in which are given the titles of most of the papers relating to this troublesone puestion, msunlly with a short digust of the prupers mentioned ... I. A. 1. Bu!l, Sill. M)rnith ("lub, Vol. V., 1. 41, Jannary, Isso.

Cores, Embotr,- Second Instalment of American Omithological bibliography. By Dr. Elliott Comes, L. s. A. Bull. L s. fime. and reogr. Surr. of Terr. Vol. V., lup. 23!1 3330, September 6, 1879.

.... This part gives the titles of "Funnal P'ublicutions" relating to central and sonth Anerici, or that portion of Amerien forming the 
so.called "Neotropical Region." .... Beginning with Marcgrare in 1648 , the list of titles is bronght down to include most of those which appeared in the first half of the vear 1879. .... Of the laborious 1e. search and eare displayed in the preparntion of this work. too great praise can scarcely be accorded.-J. A. A., Livil. Wilt. Urnith. Club, Tol. V., pp. 4", 41, January, 1880.

Dantт, Many.--On the Plains and anong the Peaks; or, How Mrs. Maxwell made her Natural History Collection. By Mary Dartt. Philadelphia: Claxton, liemse11, and Haffelfinger, $624,626,628$ Market Street, 1879. 8vo., pp. 237.

Among the many wonderful "exlibits" at the reeent Centenniul Exposition in Phindelphia, few things attracterl such gencral attention or created nore surprise... than JIrs. MI. A. Maxwell's collection of the mimals of Colorado. This little bouk before us, devoted mainly to " very intelligent and plensantly written gecount of how Mrs. Maxwell: work was accomplished, wh prepared ly a sister of that lady-naturalist. The main text of the work is intended for the general public, ; but in an "Appendix" of twenty jages are given unnotated lists of the mammals and bircts represented in the collection, the former by Dr. Cones and the latter by $\mathbf{H r}$. Kidgwiy... The list of lirds numbers 234 species The annotations relate mainly to un enmmeration of the specimens repretented, but occasionally to facts of distribution and locality of ocenrrence.-J. A. A., Brell. . Vult. Ornith. C'lub, Vol. IV., p1. 113,114 , April, 1879 .

Eldiot, Daniel Giraud. - A Classification and Sylopsis of the Trochilidie. By Daniel Girand Elliot, F.R.S.E., etc. Waslı. ington City : Published by the Suithsonian Institution. Mareh, 1879. tto., pp. xii., 277, figg. 127 (wood-cuts in the the text).

.....Mr. Elliot's eoncise and comprehensive "Synopsis" . . forms a most welcome aid to the student of this intricate group. Fonr hundred and twenty-six species are admitted as valid, distribnted among one hundred and twenty genera 'The leading charaeters of very nearly all the genera are represented by ontline figures of the head, wing, and tail. and the species are described in sutticient detail for their easy recognition. The work eloses with an appendix, giving an analytical key to the genera, and separate indexes to the generic and specific names... It will doubtless form a reference work for the gromp, not to be soon superseded, either in point of completeness or of nsefulness. -J. A. A, Bull. Wull Ornilh. Chub, Vol. IV., pp. 230-232, October. 1879 .

Gibiss, Murrts. - Annotated List of the Birds of Michigan. By Dr. Morris Gibbs. Bull. of the U. S. Geol. and Georyr. Surv. of Terr., Vol. V., No. 3, pp. 4\$1-497, Novenber 30, 1879.

Although several prior lists of the birls of Michigan have appeared, the present one is a welcome addition to our knowleige of the oruithology of that state. Mr. Gibbs's list enumerates 310 species and subspecies, and contains briet notes in their relative abundance, breeding. times of migration. etc . Althongh mainly hased on the observations of the author, he expresses lis indebtedness to nther somres of informa. tion ...-J. A. A., Bull. Wutl. Urmith. Chtb, Vol. V., p. 110, April, 1880 


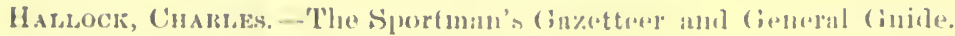
Fifth edition. By Churles Hullork.

.This book lus beenme a recognizol nuthority on ull subjets of

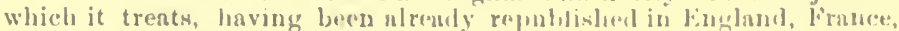

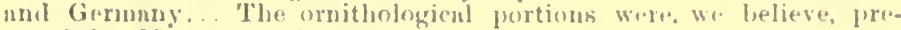

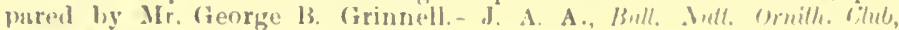
Vol. IV., p. 175, July, 1879 .

Hanve-Bnow, Joux A.-Ornithological Journal of the Winter of 1878 79, with Collected Notes regurling its Viflerets upon Animnl Life, including Remurks on the Migration of Birds in the Antumn of 1878 , and the Spring of 1879 . By Mr. Juhn A. Havir-Brown,

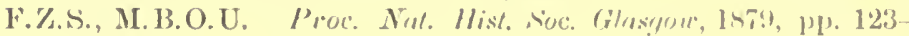
190.

... .'The winter of $1878-79$ proved of $n$ nusmal severity, and its effect upon animal life, and especially upon birl life attactet the nttention of many careful observers, Mr. Ifarvie- Brown giving a list of more than a dozen published pupers relating to the suliject. These with his own observistions and the collected notes of his many corresponilents, fim the basis of the paper ahove cited,... nenrly fifty lages heing devoted to birds . J. A. A., Bull. Sull. Ornille. Clut, Vol. V., ple. 2333, 231, October, 1880.

Harve-Brow, John A.-The Capercaillie in Seotlat. By.. A. Harvie-Brown, F.Z.S., Member of the British Ornithologists Union, etc. Edinburgh: David Douglas, 187!), 8vo., Pl. i- .xv, 1-155, maj and pll.

.....VIr. Harvie-lirown treats the genemb subject of the finpereaillic in seotland exhanstively. Beginning with such prehistoric evidence as is aftorden by the bone-caves and kitchen-mildens.... He then fresents its history prior to extivetirn, followed hy that of its restorntion, and a detailed acconnt of its increase and extension, illustrated by u map He later discusses the influences which govern its increase, its relation to the decrease of black Game, its danage to torests and grain, ete. Of specinl interest also nre his chmpters on the derivation. signitieance, and proper orthogruphy of the worl cupereallie. In short, every point of the subject is elaborated with the utmost thoroughness, the work forming a motel of its elass.-.J. A. 1., linll. Tint. Irretll. Club, Vol. V., pp. 110, 111, April, 18st.

Ixaelsold, Ersest. - Nests and Eggs of Americau Birds. By Liruest Ingersoll. S. E. Cussino, Naturalists' Agency, Salem, Mass. No (late.) Large 8vo. Part I., 1). 1-2t, 1,l. i, ii., March, lsis.

. trents of ten speeies of Thrushes, and gives illustrations of their eggs. The text includes, not onl: descriptions of the ne-sts and eggs of the species trented, but a finl anil pleasantly written account of their habits and breding rong, ... We wish that we could speak in terms of equal rommendation of the chromo-lithorraphic phates. which

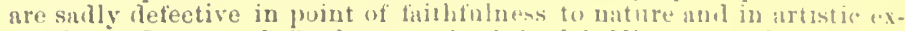

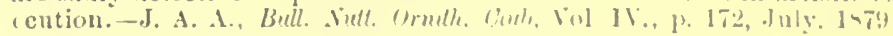

Part II., p1. 25-48, pll. iii, iv., published dugrist, 1.74.

.... we regret to perceive that the parts continue to appenr with ont dating, or any indications whuterer of the time of their publication: 
and that textual references to the tignres of the plates are still insufticiently explicit ... Mr. Ingersoll has his subject well in hand now; he contines himself strictly to the announced scope of the treatise, and holds his subject fitirly abreast of the information we have acquired respecting it. - E. C., Bult. Nult. Orrilh. (lul, Vol. V., pp. 38, 39, January, 1880 .

Part IIr., pp. 49-72, pll. v., vi., published October, 1879.

KlidDer, JoHx.-Forty Years' Notes of a Field Ornithologist, by Johu Krider, Member of the Philadelphia Academy of Natural Sciences and author of Krider's Sporting Anecdotes, Philadelphia. Giving a description of all birds killed and prepared by him. Philadelphia, 1879, 8vo., pp. i-xi., 1-81.

....MIr. Krider has "endeavored to describe and give the history of only those species of birds of the United states" which he has "col. lected and monnted," and whose nests have come nnder his personul observation .. But a casual glance through the pages of his work is enough to show that these opportunities have been sadly neglected...

In short, it is only too evident that Mr. Krider's "Notes" ure the offspring of a fading memory rather than the carefully kept data of a systematic worker.... Of the literary execution of the present work we cau say nothiug favorable....-W. B., Bull. Nutt. Ornith. Club, Vol. VII., pp. 49 , 50, January, 1882.

Kumlen, Ludwig.-Contributions to the Natural History of Arctic America, made in Connection with the Howgate Polar Expedition, 1877-78. By Ludwig Kumlien, Naturalist of the Expedition. Bull. U. S. Nut. Mus., No. 15, 1879. Birds, pp. 69-105.

... Of the 84 species noted, seven or eight relate to localities not Arctic, being species that visited the ship whlle off Newfoundland and neighboring points. Of the remander only about tweaty are land birds. 'The notes respecting many of the species are quite extended, and embrace many points of interest....-J. A. A., Buil. Nutt. Urnith. Club, Vol. V., pp. 109, 110, April, 1880.

Lawrexce, Geonge N.-Catalogue of the Birds of Dominica, from Collections made for the Smithsonian Institution by Frederick A . Ober, together with his Notes and Observations. By George N. Lawrence. Proc. U. S. Nut. IIus., Vol. I., 1879, pp. 48-69.

Lawrence, Geolige N. - Catalogne of the Birds of St. Vincent, from Collections made by Mr. Frederick A. Ober, under the Directions of the Smithsonian Institution, with his Notes thereon. By George N. Lawrence. Proc. U. S. Nut. Mus., Vol. I., 1879, 1p. 185-198.

Lawrexce, Georae N.-Catalogue of the Birds of Antigna and Barbuda, from Collections made for the Smithsonian Institution, by Mr. Fred. A. Ober, with his Observations. By (reorge N. Lawrence. Proc. U. S. Nat. Mus., Vol. I., 1879, pp. 232-242. 
Lawaesor, Grobal: N. - Catulogue of the Birds of (irenula, from un Collection male ly Mr. Fred. A. Oher for the Suithoninn Institution, ineluding others seon hy him, hut not olstuined. By George N. Lawrenes. Proc. U. s.. Nul. Mus., Vol. I., 1879, p!. $265-278$.

Lawriance, Geoboe N.-Catalogue of the Birls collectol in Martinique by Mr. Fred. A. Ober for the Smithsenian Institution. Jyy Gieorge N. Lawrence. Proc. U. s. Nul. Mus., Vol. I., 18i9, pp. $349-360$.

Lawrence, Geolage N. - Catalogue of a Collection of Birds ohtained in Guadeloupe for the Smithsonian Institution, lyy Mr. F'rerl. A. Ober. By George N. Lawrence. Proc. U. S. Nut. Mus., Vol. I., 1879 , pp. $449-462$.

Lawrence, Georae N.-A General Catulogue of the Birds uoted from the Islauds of the Lesser Antilles visited by Mr. Fred. A. Oher; with a Table showing their Distribution, and those fonnd in the United States. By George N. Lawrence. Mruc. U. S. Nat. Mus., Vol. I., 1879, pр. 486-488.

... he has coneluded his series of reports npon Mr. Ober's collections, made at various points of the Antillean chain (see above). 'The birds reported from Antigun and Barbuda number respectively' 42 and 39 species, of which one... from Antigna, is deseribed as ne'w. ... The list of birds from the island of Grenadn numbers 54 specirs,

'The birds reported from Martinique number 40 species . The Gnadelonpe species number 45 ... - J. A. A., Bull. Null.1)rmith. 'lub, Vol. IV., pl. 228-230, October, 1879.

Lanadon, Frank W.-A Revised List of Cincinmati Birds. By Frank W. Langdon. Journ. Cincinuali Soc. Nut. Mist., Vol. T., No. 4, January, 1879, pp. 167-193.

....The 256 identified species are of the following categories: ('onstant residents, 27 ; summer residents, 62 ; winter visitants, 10 ; regular migrants, 82 ; irregular migrants, 37 ; casual visitunts, 31 : species that have disappenred within torty years, 7 . It is a very gool piece of work, based in greatest part on original personial observations, very carefully elaborated, with attention not only to the unterial fucts prei. sented, but to those niceties of workmanshij, which ar too often new. lected... We are ghad to see, especially unong our younger writurs on ornithology, evidence of increased attention to detivils of execution.... an article may be male a contribution to letters as woll as to seience. It is even worth while to spell correctly. E. (., Bull. Iull. Ornith. 'lul, Vol. IV., pp. 112, 113, April, 1879.

Mears, EDgar A.-A List of the Birds of the Hudkem Highlauds, with Annotatious. 13y Eigar A. Mearns. Bull. Eissert luslilule, Vol. X., pp. 166; 179 (Introduetion and Turdus minmenrius to Parus atrienpillus, inelusive), Oetoluer-1)edember. 187s 
Mearns, Edgal: A. - A List of the Birds of the Hudvon Highlands, with Annotations. By Edgar A. Mearns. Bull. Esse.c Institule, Vol. XI., pp. 43.52 (Silta carolinensis to Dendroeca carulescens), January-March, 1879.

Bull. Essex Institute, Vol. XI., pl'. 154-168 (Dendraca carulea to Myiodiocles mitruta), July-Sejtember, 1879.

Bull. Essex. 'Institute, Vol. XI., pp. 189204 (M. conadensis to Loxia curviros(r(,), October- December, 1879.

The first part . appeared early in 1879 , and three later instalments carry the list through the genus Loxit.... while the writer draws mainly from his own experience, he occasionally indulges in quotations from other anthors, his notices of some of the species amounting to nearly complete biographies...'T'wo important features of the paper are the dates of arrival and departure,... The future instalments of $\mathbf{M r}$. Mearns's highly praiseworthy memoir may well be anticipated with interest.-J. A. A., Bull." Nutt. Orrith. Club, Vol. V., p. 175, July, 1880.

McChesney, Charles E.-Notes on the Birds of Fort Sisseton, Dakota Territory. By Chas. E. McChesney, Acting Assistant Surgeon, U. S.A. Bulletin U. S. Geol. and Geogr. Surv. Terr., Vol. V., pp. 71-101, February 28, 1879.

...form a valuable contribution to the oruithology of a little known portion of the Northwest, namely, the elevated platean in Da. kota, known as the "Coteru des Prairies." .. The "Notes" are baseil on an experience of three years in the neighborhood of Fort Sisseton, and record 157 species, respecting most of which there are copions and interesting annotations.... Dr. McChesney's report was transinitted to Dr. Coues for publication, and appears to have had the benefit of his revision....-J. A. A., Bull. Nutt. Umith. Chub, Vol. V., pp. 42, 43, Jan. vary, 1880 .

McChesney, Charles E.-Report on the Mammals and Birds of the General Region of the Big Holn River and Mountains of Moutani Territory. By Charles E. McChesney, U. S. A. Being Appendix SS 3 of the Report of the Chief of Engineers for 1879.

...proves an interesting addition to the faunal records of the West ... The list of 100 species of birds is the result of less than a month's investigation-from August 15 onward-_... The notes, though brief, are usually sufficient to indicate the occurrence of each species, and, as in the greater number of cases they result directly from the anthor's own observations, they carry with them the value of perfect anthenticity... contains the name of not a single exclusively Eastern species ....-H. W. H., Bull. Nutt. Orrith. Club, Tol. Y., pp. 107, 10s, A pril, 1880.

Merrili, Jayes C.-Notes on the Ornithology of Southern Texas. Being a List of Birds observed in the Visinity of Fort Brown, Téxas, from February, 187t, to June, 1878. By James C. Merrill, Assistant Surgeon U. S. Army. Proc. U. S. Nat. Mus., Vol. I., 1879, pp. 118-173.

.... Two hundred aud fifty-two species and varieties are given in all, and the character of their presence is in most cases satisfactorily de- 
fined ...the nests, eggs, and breeding linbits of 'lexan hirils reeeive the lnrger share of attention, and much of the unt ter pertuining thereto is as valunble as it is now ... Numerons notes hi Vr. Ridgway und Dr. Brewer occur thronghont the paper am greatly culusuce its value ... In a few detnils of arrongement the puper is open to miverse criticism ... Altogether. however, the paper is a most exeellent on", and its contents supply a fund of information the lack of whieh has been long felt.

W. 13., Brell. Sult. Ornilh. Cluh, Vol. IV., p1). 50 52, dun แary, 1879.

liathbun, Fibask R.-A lievised List of Birls of Central New Fork. Based on the Observations of Frank R. Rathlin, H. Gilbert Fowler, Frank S. Wright, Sumuel F. Rathlun, in the Counties of Caynga, Ononduga, Seneen, Wayne, and Fates. Collated and prepured for P'ublication by Frank R. linthbus. Auburn, N. Y.: Daily Advertiser and Weekly Jonrual Book and Job Printing Honse, April 17, 1879.

.... in the present "lievised List" are enumuruted 236 , slowing nn aldition of 46 species... In conchusion, it is lut just to say that "The Ornithological four" have in their "Revised List of Biris of Central New York," not only done themselves great eredit, but have made n contribution to our sicienee which must fong remain authority enncern. ing the reginn of which it trents. I consider it the best list of the birds of any part of this State that has appeareel for mnny years.- C. H. M., Bull. Null. Ornith. Club, Vol. IV., pl. 172 175, July, 1879.

Ridgwar, Robers.-On a new Hnmming-bird (Atthis ellioti) from Guatemali. By Robert Ridgway. I'roc. Li.S. Nal. Wus., Tol. I., 1879, pp. 8-10.

Ridaway, Ronent.-A Review of the American Species of the Genns Scops, Saviguy. By Robert Rilgway. Proc. I'. S. Yvut. M/s., Vol. I., 1879, pp. 85-117. Anthor's separates issued Angust 6. 1878.

Ridgway, Ronert. -Description of Severul New speeies and Grographical Races of Birds Contained in the Collection of the United States National Musemm. By Robert Iiilgway. J'roc. $l$. s. 'Nat. Mus., Vol. I., 1879, pp. 247-252. Author's separates issned December 10, 1878.

Ridgwar, Roberr.-Deseriptions of Two New Squeins of Birts from Costa Rica, and Notes on other Rare Specias from that Conntry. By Robert Ridgway. Proc. U. s. Tat. M/s., Val. I., 1879, p'l. 252-255. Anthor's separates issned Decembrr 10, 1878.

Ridgwax, Robeltr,-Deseriptions of New Spereirs and Inees of American Birds, ineluding a Synopsis of the Grums lyrauuas, Cuvirr. By Robert Rialgway. Proc. U. S. Tat. Mus., Vul. I., 187!, M!. 466-186. Anthor's separntes issued April 25, 1579.

These (five) papers all notably evinee Mr. liklywy is well-known

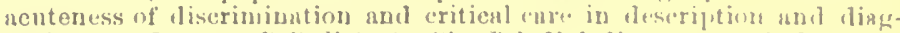

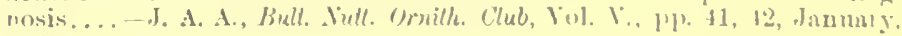
$18 \rightarrow 0$. 
Roosevelt, Theodone. - Notes on some of the 13irds of Oyster Bay, Long Island. By Theodore Roosevelt. 8vo, 1 p. Mareh, 1879.

This is a brochnre of a single leaf, containing notes on serenteen species, observed at the above-named locality, by Mr. Theodore Ronsevelt ...--J. A. A., Bull. Niell. Omilh. Chul, Vol. IV., J. 171, July, 1879.

Sexnetr, Geonge B.-Further Notes on the Ornithology of the Lower Rio Grande of 'Texas, from Observations made during the Spring of 1878. By George B. Sennett. Wlited, with Annotations, by Dr. Elliott Cones, U. S. A. Bull. U. S. Cieol. and Geogr. Surv. of Ter\%, Vol. V., No. :3, p1. 371-4t0, Novemher 30, 187 !).

The report of Mr. Sennett's three montls' work (in April, May, and June) in 1878. vear Hidalgo, Texas, adds greatly to our knowlerlge of the life-histories of many species of which we previously knew but little. .... In addition to the notes on the habits of the hirds olsserved, which in the case of the less known species amounts in some instances to full biographies, the author presents us with extender tables of measurements, gives detailed deseriptions of nest and eggs, and occasionally discusses points of relationship and nomenclature.... The "Notes" relate to 165 species, and altogether form one of the most valuable of the many recent contributions to local ornithology. -J. A. A., Bull. Nutl. Urnith. Clul, Vol. V., p. 111, April, 1880.

Silarpe, R. Bowduer. - Catalogue of the Birds in the British Museum. Vol. IV. Catalogne of the Passeriformes, or Perehing Birds, in the British Musenm. Cichlomorphe: Part I., containing the families Campophagidie and Museienpidre. By R. Bowdler Sharpe. London, 1879. 8vo., pp. xvi., 494, pll. xiv.

Of the Compophagilue 148 species are described, of the Muscicapida? 391. In style of trentment and general character this volume is sinilar to the earlier ones.....J. A. A., Bull. Witl. Orrith. Clul, Vol. VIII., p. 99, April, 1883.

Vogr, M. C.-L'Alehíeopteryx macronra.-Un intermédiaire entre les oiseanx et les reptiles. Par M. C. Vogt. La Revne Scientifique, 2e Séries, 9e Année, No. 11, 13 Sept. 1879, pp. 241-248, figg. $18-21$.

This speeimen was found by M. Haeberlein in the same slates as the first.... From what Professor Vogt has discovered by a cursory examination there ean be no donbt that much of great interest will be learned when this fossil is properly worked out from the matrix.—J. A. Jeffries, Bull. Tutt. Ornith. C'tut, Vol. VI., pp. 107-109, April, 1881.

\section{0.}

Belt, Robert.-List of Birds from the Region between Norway Honse and Forts Chmrehill and York. [By Robert Bell.] Greological Survey of Canada. Report of Progress for 1878-79 (1850). IV., Appendix vi., pp. 676-706.

.... an annotated list of 55 species, of much interest from the localities of observation.....-J. A. A., The Auk, Vol. II., p. 209, April, 1885 . 
Buayton, Alsmaert W. -A Catalogne of the Birls of Indina, with Keys and Descriptions of the (iroups of grentest Interest to the Hortienlturist. By Alembert W. Brayton, B.S., M.1). Transactions of the Indianu Ilorticullural Siociety for 1879, 11p. 89-166. Indiumupolis, 1880.

... is intended as a "practical hund-book" of the lirds of Indiann, und sems well ealeulated to meet this ropuirment. It is avowedly a compilution.... we note little in Dr. Bruton's pujer tlut is new to ornithologists, but much that is given from good unthorities. Short notes are added relutive to the ubumlunce, labits, mnd ranson of occurrence of the 306 speeies enumeruted. The pun eloses with an index to the names of the genern and higher gromps, with their deriva. tions, a "glossary" of the specilie nnumes, and un index of Englist numes. ...-J. A. A., Bull. Wult. Orrith. Chth, Vol. V., p). 17I, 175 , July, 1880.

Buewe1, T. M.-Notes on the Nests and Eggs of the Fight Nortl American Species of Empillonaces. Jy T. M. Jirewer. Proc. U. S. Nat. Mus., Vol. II., 1880, 1)1. 1-10. Antlior's sepurates issued April 29, 1879.

Following the mensmrements and descriptions of the nests and eggs of these eight species are several puges devoten to a consilerution of the nests and eggs of E. flaricentris ...-J. A. A., Bull. Vidt. Uruilh. Club, Vol. IV., p. 232, Oetober, $187 \%$.

Cooper. J. G. - On the Migrations and Nesting Hahits of West. Coast Birds. By J. G. Cooper, M.D. Proe. U. S. Val. Vus, Vol. II., 1880, p1). 211-251. Author's separates issued Jan. 20, 1860.

.... Dr. Cooper has tabulater a large anount of vuluable informution respeeting the times of arrival, departure, and nesting of many of the common West-Const land birds, based matinly on his own obscrvations .... The number of species tubluated is 73 ... Dr. Cooper has here begun a good work in a praiseworthy way, ...- J. A. A., Bull. - Vill. Uruilh. Club, Yol. V., p. 232, October, 1880.

Comy, Cirarles 13.-Birds of the Bahama Islanis; containiug muny Birds new to the Islands, and a Number of undescribed Winter Plumages of Nortlu Ameriean Birds. 13y Charles 13. Cory, Anthor of "A Naturalist in the Magclalen Islamis," vie. Illustrated. 13uston: Published by the Author, 8 Arlington sitreet, Jioston. 1880. 4to., pp. 3j0, with 8 colored plates.

... forms a valuable addition to on knowledge of the birals of these islands. Of the 149 species recorded, all but alont , 31 were met with hy Mr. Cory, ...In addition to the short descriptions of the sprecies, the relative abundance and distribution of the species is noted, to which is frequently added a short account of their habits .... J. A. A., liull. Sutt. Oruith Club, Vol. V., p 107, April, Isso.

Cores, Eubotr. - Third Instaluent of American Ornithological Bil. lingraphy. By Dr. Elliott Cones, U. S. A. liull. U. S. Com. 
and Geogr. Surv. of Terr., Vol. V., No. 4, 1879, pp. 521-1,066. P’ublished Sept. 30, 1880.

... is by far the largest of the three,.... and completes his "Bibliography of Ornithology so tar as America is concerned"... The present third instalment consists of a selection of titles belonging to the "systematic" department.... In reference to the clinracter of the work, it is enough to say that it is fully up to the high standard of excellence of the previons instalments .. Its utility no working ornithologist can fail to highly apprecinte, while it will form an enduring monument to the author's patience, industry, and thoroughness of research.-J.A. A., Bull. Nutt Ornill. Club, Vol. VI., pp. 44 16, January, 1881.

Coucs, Eluiotr. - Fourth Instalment of Oruithological Bibliography: being a list of Fannal Publications relating to British Birds. By Dr. Elliott Coues, U. S. A. Proc. U. S. Nut. Mus., Vol. II., 1880, pp. 359-476. Published May 31, 1880.

This "Fourth Instalment" is of the same character as the first two, and attempts to do for British Birds what those did for American Birds ...As it is, being accurate as far as it goes, it will prove of great usefulness, and is entitled to the cordial welcome it will donbtless receive. -J. A. A., Bull. Nutt. Ornith. Club, Vol. VI., p. 46, January, 1881.

Fonbes, S. A.-Studies of the Food of Birds, Insects, and Fishes, made at the Illinois State Laboratory of Natural History, at Normal, Illinois. By S. A. Forbes. Illinois State Laboratory of Nutural History Bulletin, No. 3, November, 1880, 8ro., pp. 1-160.

.. a further report of his studies, about seventy pages of which relate to birds....'The species of birds investigated are, as before, the 'Thrushes and the Bluebird ...-J. A. A., Bull. Nutl. Orrith. Club, Vol. VI., p. 110, April, 1881.

Freke, Percy Evixs. - A Comparative Catalogue of Birds found in Europe and North America. By Percy Evans Freke. Dublin, 1880. Svo., pp. 44. From the Scientific Proceedings of the Royal Dublin Society.

....forms an important contribution to geographical ornithology, Abont 22.5 North American species are enumerated.... Of about 100 species that may be considered as merely strigglers from one continent to the other, fully four-fifths are North American... Despite a few typopographical errors...the paper gives evidence of careful preparation and almirably fills a long-standing gap in ornithologieal literature.-J. A. A., Bull. Niett. Ornith. C'lub, Vol. V., pp. 173, 174, July, 1880.

Lextiy, 'L'homas G. - Illustrations of Nests and Eggs of Birds of the United States, with Text, by Thos. G. Gentry. Philadelphia . J. A. Wageuseller, Publisher, No, 23 North Sixth Street, Copyright by J. A. Wagenseller, 1881. 4to., parts 1-25, pp. 1-300. 54 colored chromo-lithograplss and chromo-portrait frontispiece of che author. 1880-82.

.... the plates were executed by Mr. Edwin Sheppard, "subject to the suggestions and dictations of the author." The title is misleading 
for instead of treating of ull the species fonnd in the Inited States it deals with but tifty .. The typography and presis work are good, but the plates fall far sbort of deserving the sume praise... of most of the plates... the perspective is very bud ....nnd .. nenrly all huse the uppenrance of cheap chromo-lithogruphs...the work does not eontain anything appronehing a complete "detailerl necount of the habis" of a single species ...instenl of becoming un muthority.... Mr. (ientry's book on nests and eggs must inevitably find its level ulougside such unreliable and worthless productious us Jusper's "Birds of North America"....-C. H. M., Bull. Nult. Ornith. Club, Vol. VII., 111. 246 2.15, October, 1882.

Grega, W. H.-Revised Catalogne of the Birds of ('hemung Comnty, New York. By W. H. Gregg, M.D., Elunira, N. Y.: O. H. Wheeler. 1880.

...we have a list of the birds of a locality to which little attention has been paid by ornithologists. The list of whieh this is a revision was issued ten yenrs ago ...In all. 217 species are enumerated... A few lines of notes accompany each name ...-E. I., Bull. lull I rnith. (lub, Vol. Y., p. 173, July, 1880.

Harvie-Brows, J. A.-The Capercaille in seotland. Iy J. A. Harvie.Brown, F.R.S. Scoltish Nuluralist, Tuly, 1880.

....Mr. Harvie-Brown publisued last year nn exhunstive littie work on the Capercaillie in Scotlund The prevent paper is u contiunstion of the Appendix of that work, giving an acconnt of its extension in 1879 , with a few additional references to enrly records of its presence in Scotland and Wales, -J. A. A., Bull. Till. Orith. Club, Vol. VI., p. 4t, January, 1881.

Harve-Brown, Johx A., and Cordeaux, Jorn.-Report on the Migration of Birds in the Antumn of 1879. By John A. HarvieBrown and John Cordeanx. Zö̈logist, May, 1850, pp. 161-204.

... two woll-known British ornithologists, have set themselves seriously at work in the matter of collecting exuct ilata respectung the movements of birds during their migrations along the consts of (irent Britain.... Observations made at other points are incilentally incorporated, including Herr Gütke's report from Ileligoland. The work so earnestly begun.... should be a stimulus to onneurrent action on the part of others, and nowhere are the conditions more fivorable for systematic work than in the United States. -J. A. A. Brelt. Jult. Ornille. Club, Vol. V., pp. 175-177, July, 1880.

Harve-Brown, John A. - Second Report on Seottish OrnithologyOctober 1, 1879, to September 30, 1880. Compiled by Mr. John A. Harvie-Brown, F.R.S.E., ete. Proc. Nul. Mlist. Sinco of Glusgow, Vol. IV., Part II., A pril, 1880, 1). 291 326.

... The report gives a "Journal of the Winter of 1479 - 40 " . the report gives observations on soms 6.5 to 70 speeies.. The report abounds with especially suggestive ohservations in relation to little understood points of bird-life....-J. A. A., Butl. Null (m)ith. Cluth. Vol VI., p. 174, July, 1881 . 
Hensfraw, Н. W.--Ornithological Report upon Collections made in Portions of California, Nevala, and Oregon. By H. W. Henshaw. Annual Report of the U. S. Giengr. Surveys acest of the Hundredth Meridian, for 1879. Appendix L of the Report of the Chief of Engineers, Fcbruary, 1880, pp. 282-:135.

Mr. H. W. Henshaw's "Ornithological lieport" for the tield seasons of 1877 and 1878 is mneh more than a record of field observations for the seasons named, treating as it does most ably, thongh briefly, of the relationships of the members of several of the most pnzaling groups of North American birds. In addition to having aecess to a large amount of material, much of which the anthor collected himself, he is able to bring to bear upon the questions at issue an intimate knowledge of the birds in life, and of the varying conditions of environment which surround the forms treated ... In relation to the habits of the species mentionel, the Report contains much that is new, ....J. A. A., Juell. Nutt. Ornith. Club, Vol. V., pp. 10:5-107, A pril, 1880.

LAxqdox, Fraxk IV.-Ornithological Field Notes, with five Additions to the Cincinuati Avian Fauna. By Frank W. Laugdon. Journ. Cincinnati soc. Nul. Hist., July, 1880, pp. 121-127, 1 pl.

'These notes ...virtually form a supplement to the same anthor's excellent "Revised List of Ciucinnati Birds" publisher in 1879.... They relate to 40 species .. Among the points of special interest are the capture of two specimens (male and female) of Kirtland's Warbler (Dendrace kirtlandi) near Cleveland, May 4 and 12, 1880.... The paper is preceded by Dr. Langdion s description of a new species of Itelminthophaga.....J. A. A., Bull. Titt. Ornith. Cluh, Vol. V., pp. 232, 233, Octover, 1880 .

Marsh, Othniel Charles.-Odontornithes: a Monograpl on the Extinct Toothed Birds of North America; with thirty-four Plates and forty Wood-cuts. By Othniel Charles Marsh, Professor of Palaontology in Yale College. 1 vol. 4to. Pp. i-x., 1-201, figg. 1-40, pll. i-xxxiv., each with 1 explanatory leaf. Forming Vol. VII. of the Reports of the Survey of the 40th Parallel.

....It is the first of a series of monographs designed to make known to science the extinct vertebrate life of North America, in the investigation of which the author has passed the last ten years. It is unquestionably the most magnificent contribution ever made to our knowledge of extinct birds ... It is safe to say tbat no single memoir on fossil birds hitherto published can be compared with this in aceurney of detail, in beauty of illustration, and in value of results attained ... The present volume is based on the remains of more than one hundred different individuals of the Odontornithes procnred in the Cretaceous deposits of the West during the last ten years ... The work of Professor Jiarsh, as a whole, is an unmeasured advance upon all previously obtained knowledge of Cretaceons birds. The present volume is divided into two parts, the first treating of Ilesperomis, the second of Iclthyormis and Apatomis, the entire skeleton of typical species being described with elaborate detail, and figured in the most perfect manner.. The Appendix presents a sypopsis of the nine genera and twenty species of American Cretaceous Birds....-E. C., Bull. Sult. Ornith. Club, Vol. V., pp. 231-236, October, 1880 . 
Marnalid, C. J.-The Birds of Florida, with the Wuter and Game Birds of Eastern Nortl America. By C. J. Mayuard. Illustrated. P'nblished by C. J. Maynard \& Co., Newtonvill', Mass.

....the eighth purt has just been reecived The text is ly far the most satisfactory purt of the work, and eontuins much of interest. though, perhaps, too much space is given to the lublits of solne spucies as observed in Now England and elsewlere ...Certain changes are mude in nomenclature and clnssifieation, notully raising the Kingfishers und Nighthawks to the rank of orlers ...l'lates i., ii., iii., and xii. ure passable, ...lint the others are extremely poor, l'ate vii., in Part vi., has figure's of sixty-six eggs of sixty-fonr species.... - I. C. MI., Bull. Nut!. Ornith. Chel, Vol. IV., 11p. 114, $11^{\circ}$, April, 1879

Marsalb, C. J.-The Birds of Eastern North Amerien, with origium Deseriptions of nll the Species whieh oecur enst of the Mississippi River between the Aretic Cirele and the Gulf of Mexieo, with full Notes upon their Hubits. By C. J. Maynard. Containing thirty Plates drawn on Stone by the Antlor, C. J. Maynard \& Co., Newtonville, Mass. 4to. (Thirteen Purts issued.)

See ubove, same work under another title.

... the peninsula (of Florida) lias never received so much attention at the lunds of any one ornithologist, not excepting Andubon, as from Mr. Maynard. It is a matter for regret that the later plans of the work had not been its original one. I Iad such been the case, the author would have been spared the necessity - if indeed it be a necessity-of repenting verbatim in the "IBirds of Eastern North America" many pages of descriptive matter and biography which appenred in tho "Birds of Florida".... In his classification Mr. Alaynard has departed in many particulars from beaten paths, the basis for most of his changes being anatomienl ...It is evident that the "l3irds of Eastern North Amerien " was written more with a view of striking the popular taste than as a hand-book for the systematic ornithologist, .. In con. clusion, we may be permitted to express the feeling that the portions of the work now hefore us do not by any means represent the author's best efforts. and that in certuin particulars, but especially as regards the plates, he is eapable of placing the work on a far higher plane than can at present be necorded it.-II. W. II., Bull. Vilt. Urnith. (lub, Vol. V., pp. 170-173, July, 1880.

Menins, Evgar A. - A List of the Birds of the IIudson IIighlands, with aunotations. By Edgar A. Mcarus. Bull. Essers. Instilute, Vol. XII., pp. $11-25$ (. Eyiothus linuria to (Uniscalus purpurens), Jannary-June, 1880.

Bull. Essex. Instimte, Vol. XII., 1). 109 128 (Cortus frugivorus to Orty.x virginiana), July September, 1850.

The high proise nceorled the carlier instulments is equally merited by those now muder notice, Mr. Menrns's "I Ist of the Birds of the II dson Highlands" ranking easily among the best of onr long lisi 
of contributions to local ornithology.... In respect to nomenclature, the list is abreast with the lat est well.grounded innovations. - J. A. A., Bull. Nutt. Ornilh. Club, Vol. VI., p. 172, July, $1 \times 81$.

Minot, H. D.-The Diary of a Biri. Jyy H. D. Minot. Boston: A. Williams of Co., 1880, 8vo., pp. 38, cuts.

This entertaining and pleasantly written pice of bird-gossip is represented to be a translation of a "Diary" of a "Black-throated Green Wartler," and reeounts, anong other things the doiugs of "a grand mass meeting" of the birds to diseuss "lhe Destruetion and Extermination of Birds; how caused and lıow to be prevented." in which varions members of the great bird convention relate theil grievances.... The olject of this attractive little brochure is to awaken popular interest in the general subject of the better protection of our birds, not only against the professional market gunner, but from their wholesale destruction to meet the demants of the milliner.--J. A. A., Bull. Nutt. Omilh. Club, Vol. V., p. 112, A pril, 1880.

Neunding, H.-Ornithologische Beobachtungen aus Texas. I. Von H. Nehrling. Monatssehrift des Deutschen Vereins zum Schutze der Vogelwelt, V Jahrgang, No. 7, Juli, 1880, pp. 122-139.

These observations consist of a running commentary on the more common birds met with by Dr. Nelurling in March, April. and May, 1879, in Lee and Fryette Countifs. Texas. It is apparently the first of a series of papers on the birds of Texas... with, incidentally, notes on the mammals, the plants, and the general character of the country... --J. A. A., Bull. Nutl. Urnith. Club, Vol. VI., p. 109, A pril, 1881.

Ober, Frederick A.-Camps in the Caribbees: The Adventures of a Naturalist in the Lesser Antilles. By Frederick A. Ober. Boston: Lee and Shepard. New York: Cliarles T. Dillingham. 1880. 8 vo., pp. xviii, 366 , with 34 illus.

....The general text introduces a good deal of ornithological matter, which will he found of interest and value, and the appendix is entirely devoted to this sulject. It gives Mr Lawrenee's sunmary list of the species, 128 in number.... and also reproduces the original descriptions of all the new species discovered by the energetic and snccessful explorer.--E. C., Bull. Sutt. Ornith. Club, Vol. V., p. 179, July, 1880 .

Reichenow, Axtox, and Schalow, Hermasx.-- Compendium der neu beschriebenen Gattungen und Arten. Von Anton Reichenow und Hermann Schalow. Journal für Ornithologie, 1S79, pp. 308-329, $420-437 ; 1850$, pp. 97-102, 194-209, 314-324.

The authors of the "Compendium" are placing ornithologists under a debt of gratitude in promply bringing together the dingnoses of the new genera and species of current ornithological literature. The last instalment apparently covers the first half of the year 1880 , and the families from Cuculide? upward through the Oscines......J. A. A., Bull. Sutt. Omith. Club, Vol. VI., p. 111, April, 1881.

Reichenow, Anton, and Schulow, Hermanx.-Zoologischer Jahresbericht fiir 1879. Herausgegeben von der Zoologischen Station 
zu Nenpel. liedigirt von Prof. J. Victor Carus (W. Huglemann, Leiprig). 5. Aves. 13al. II., Pl, 1108-1161. Referenten Dr. Ant. Revelnenow und H. Selunlow.

....'The report nppents to be very enrefully und sutinfactorily prepmred. the monotations leing sulliciently full and explicit. J. A. A., biell. Vutt. Ornilh. Clul, Vol. VI, 1. 111, April, Issi.

linurats, Thomas S.-The Convolutions of the Truchen in the Sand. hill mul Whooping Cranes. By 'Thomas S. Roherts, M.1). . Imer. iean Naluralist, Pol. XW., Fohruary, 1880, 1). 10s 114, figg.

... Ir. linherts has given an whirable presentution of the trachenl chnracters of onr two lnrger speeies of Cranes, jllustrate: with euts .....J. A. A., Bull. Vill. Ornih. (lul, Vol. V., J), 17!, 180, July, 1880.

STentrs, Wromen A. - List of Birls of Fishkill on Hndson. N. Y. By Winfril A. Stenrus. 8vo, pp. 16. withont duto or publisher's impress. Published July 10, 1880.

This is u briefly annotated list of about 130 species, based on ten months' observations by the anthor in the vicinity of Fishkill... the list, though very incomplete, is doubtlens trustworthy ... - J. A. A., Bull. Nult. Ornith. Club, Vol. V, 1. 233, October, 1880.

Sreere, J. 13.-A Ijist of the Mammals und Birds of Aum Arbor und Vieinity. By Professor J. B. Steere. 8ro., pl). 8, 1880.

'This briefly annotaterl list of 111 species (of birls) is good as far as it goes "....with the exception of $a$ few, given upon the unthority of labeled specimens in the IInsem, it is the result of about three years' collecting and observation in this vicinity." J. A. A., Bull. Nutt. Ornith. Club, Vol. VI., 1). 46, January, 1881.

\section{1.}

Baller, H. B.- "Forest and Stream" Birl Notes. An index and summary of all the ornithological matter contained in "Forest and Stream," Vols. I-XII. Compilerl by H. B. Builey. New York: F. it S. Pub. Co., 39 Park Row, 1881. 8vo., paper, pp. iv., 195.

His work is more than n more "lphatetical list of names, followed by reference figmes; for it includes . . a smm mury of each article indexed ...The Index nlso includes anthor's names, mol among these the anthorship of many psendonyms and intinl signatures are for the first time properly exposed. The sumulation of the birl-matters seews to be quite complete and is eertninly extensive... - E. C.. Bull. Nult. Ormeth. Clut, Vol. V11., p1). 175, 176, July, 185:.

Freke, Pencr Evass - On Birds observed in Amelia Comnty, Virginia. By Percy E. Freke. Scientitic Proc. Royal Jublin society, Vol. III. Part III. |Read February 21, 1sis1.|

.. Mr. Freke has done goot sersien in publishing the results of six yenrs' olsservations in Amelin Comnty, at a point nbout thirty 
miles sonth of Richmond. His list, which is treely annotated, includes 112 species... The anthor has evidently fullen into sone confusion re. garding the spotted-brensted 'Thrushes of the genus Timilus . . will be: rearl with interest, not only as an exponent of the ornithology of u pr.:viously unworked section, but ulso us embolying a foreigucr's pleasantly tok impressions of many of onx fumiling bircls - W. B., Bull. Nult. Ornith Club, Vol. VII., 1. 48, Janmary, 1882.

Freke, Percy Evaxs.-Nortl Americin Birds crossing the Atlantic. By Perey Evans Freke. 8vo., pp. 11. Scienlific Proc. Royal Dublin Society, Vol. III., 1881.

This paper is based on the anthor's "Comparative Catalogne of Birds found in Europe and North Anerien "... of which it may be regarded as in part it summary, us also a most valmable fesmme of the general suliject of North American birds oecurring in Enrope. The number of species is 69 ; the total number of occurrences, $494 \ldots$ J. A. A., Jull. Nutl. Oruth. Chub, Vol. V1lI., p1) 114, 115, A pril, 1883.

Freke, Pency Evans. - On Emopean Birds olserved in North Amerien. By Percy E. Freke. Zjöloyist, September, 1881.

The total number of species included in this list is 56 , of which ! are regarded as artificially introducud... The list scems to have been most carefully worked out, and may leservedly stand as a companion piece to Mr. J. J. Dalgleish's "List of" (Jecurrences of North Anerican Birds in Europe," published in Volume V' of this Bulletin ....-J. A. A., Bull. Nutt. Ornith. Club, Vol. VIII., p 115, A pril, 1883.

Garrod, Alfred Hexry, and Fonbes, W. A.-In Memoriam. The Collected Scientific Paper's of the late Alfred Henry Garrod, M.D., F.R.S., etc. Edited, with a biograplical memoir of the anthor, by W. A. Forbes, B.A., ete. London: R. H. Porter, 6 Tenterden Street. 1881. 1 vol., 8vo., pp, xxvi., 538, pll. 33, frontispieee (portrait) and many cuts in text.

... Of the anatomical papers in the present volnme, some 73 in number, more than half relate to birds, describing conditions of the osseous, muscular, respiratory, vascular, digestive, and nervous systems .... and discussing in candid and -cientific spirit . . the benting of the anatomical points upon classitication. Of the aceuracy and high rate of reliability of these papers there can be no question among them is an entirely new classiticntion of birds, based primarily upon the anbiens [muscle]....--E. C., Bull. Null. Onrith. Club, Vol. VII., p1). 43, 44, Jannary, 188:.

Godman, F. Drcane, and Salvis, Oslzert.-Biologia CentraliAmericana; or, Contributions to the linowledge of the Fanua and Flora of Mexico and Central America. Edited by F. Ducune Godman and Osbert Salvin. Zö̈logy, Parts 1-X. Aves, by O. Salvin and F. D. Godman, pp. 1-152, pll. j-x. 4to. London: Published for the Editor's by R. H. Porter, 10 Chandos Street, 
Cavendish Sipunre, W., und Dulnu of Cu, Sohosifunre. Soptem. ber, 1879 April, 1881.

.... As the title indicutes, the work trents of the fanna and thors of Mexico and Central America ... The ornithological portion is by the elitors . Of ench species a Nhort Latin description is given, and all the more important references to the literature are inly eited. . The ten plates thus fur published contain higures of 2:) hitherto unfigured species ... The importance and usefulness of the present work cunnot ... be ensily overestimated.... The excention of the "liulogia" as regurds typography and illustrations... is excellent ... J. A. A., lubl. Sintl Ornith. Club, Vol. VII, pp 174-176, July, 1881.

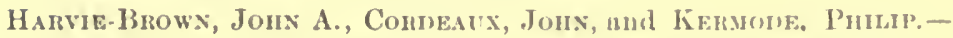
Report on the Migrntion of Birds in the Spring and Antunu of 1880. By John A. Hurvie-Brown, F.I.S., F.Z.S., John Cordeaux, and Philip, Kermode. London: W. S. Sonnenschein * Allen, 15, Paternoster Square. 1881. 8vo., pl). 120.

.... we now.... call attedtion to several late reports and japers on thr same subject [migration of birds]. 'The report for losu torms a pamphlet of 120 octavo pages ...printed schedules and letters of instruction were sent to 39 stations ... on the east coast of scotland .

to 44 on the east coast of Englnnd ; to 38 on the west const of Scotlind ....and to $3 y$ on the west const of England, or to 160 strtions in all. from 106 of which reports were receivel... The report for 1881 is of similar scope and character.....J. A. A., Bull. Vutt. Ornilh. Club, Vol. VIII.. pl. 228, 229, October, 1883.

Hanve-Brows, Jons A.-Paper on the Migration of Birds upon our British Coasts, read before the Stirling Field Club, on Tuesday, 13th Decenber, 1881, by J. A. Harvie-Brown, F.R.S.E., F.Z.S., ete. Stirling: Printed at the Jourual amd Advertiser Office. 1881. 12 mo., pp. 12.

Hatcr, P. L.-A List of the Birls of Minnesota. By Dr. P. L. Hatch. Ninth Ann. Rep. Geol. and Viat. Hist. surv. Minn., for 1880. 1881, pp. 361-372.

.... list of $28 \mathrm{I}$ species, briet!y annotated ... E. C., Bull. Wull. Urnith. Clnb, Vol. VII., 1). 47, Jamuary, 1882.

Holtenhopf, G., Jk. - A Collector's Notes on the Breeling of a few Western Birds. By E. [i.e., G.] Hulterhoff, Jr. Americun Naluralist, March, 1881, pp. 208-219.

... The observations here recorded were male in sonthern Californin in the spring of 1880 and have refirence to some 11 species.... J. A. A., Bull. Niull. Ornilh. Club, V'ol. V゙T., p. 173, Jnly, 1881.

Hofrsan, W. J.-Annotated List of the Birels of Nevida. By W. J. Hoffman, M.D., Bull. L. S. lreul. und lieory. Surr. of Terr., Vol. VI., No. 2, Sept. 19, 1881, pp. 203-256, and Map.

....The list is based partly upon the writer's personal exporience in the field during the season of 1571, hnt mainly upun .. previously 
publisheal reports ... It lience partakes largely of the nature of a compilation, although the author's original notes are by no means few or uninteresting.... The paper.... closes with a bibliographical list of the chief publications relating to the region considered, and an excellent map of the State.... Dr. Hoffman's paper ... should find a place in the hands of every working ornithologist.-W. B., Bull. Nitt. Umith. Clnb, Vol. VII., p. 51, January, 188:.

Kruknnera, C. Fr. W.-Die Furbstoffe der Federn, in dessen vergleichend-physiologische Studien. Von Dr. C. Fr. W. Krukenberg. I Reihe, $\mathrm{V}$ Alth., 1881, pp. 72-92. Plate iii.

This paper, the first of a series, seems to be the product of unore careful work than previous publicitions on the snbject [coloring inatter of fenthers]....-J. Amory Jeffries, Bull. Vutt. Ornith. (thut, Vol. VII., pp. 114, 115, April, 188:.

Langdon, F. W.-Field Notes on Louisiana Birds. By Dr. F. IV. Langdon. Journ. Cincinnati Soc. Net. Ilist.. July, 1881, pp. 145155.

...." a record of . ...the month ending April 17, 1881 at 'Cinclaire' ....in the parish of West Baton Ronge"... the paper will be welcomed as an acceptable contribution to our knowledge of a region which lias been nearly a terra incognita to ornitbologists since the day's of Aurlubon. -IV. B., Bull. Nutt. Ornith. Club, Vol. VII., pp. 40, 49, Jinuary, 1882.

Langdon, F. W.-Zoölogical Miscellany, edited by Dr. F. W. Langdon. Jour. Cincinnati Soc. Nat. Hist., Vol. IV., Dec., 1881, pp. 336-346.

..."facts.... respecting the structure, the life listory, or the geographical distribution of the various species of animals constituting the Ohio Valley Fanna." The part betore us includes sections on manmalogy, ornithology, herpetology, ichthyology, couchology, and entomology....the editor contributes a short but useful paper on the "Introduction of Europenn Birds" ...-W. B., Bull. Nill. Ornith. Clul, Vol. VII., pp. 50, 51, January, $1 \times 82$.

Lawrence, Georae N.-Description of a New Subspecies of Loxigilla from the Island of St. Christopher, West Indies. By George N. Lawrence. Proc. U. S. Nat. Mus., Tol. IV., 1882, pp. 204, 205.

....Mr. Lawrence describes a new subspecies of Loxigilla ( $L$. p portoricensis var grandis)....-J. A. A., Bull. Lutt. Ornith (tul), Vol. VilI., p. 114, April, 1883.

Macoun, John.-Extract from a Report of Explorition by Professor John Macoun, M.A., F.L.S. Report of Deplariment of Interior (Ottawa, 1891 ?) 8vo., pp. 48.

...chiefly (pp. 840 ) of l'rofessol Macoun's own report of his explorations during the summer of $1880 \ldots$...north of our territories of Dakota and Montann....the present paper possesses decided value, as 
the observer nppenred to have puill specinl uttution to the distribution of bircls in the wide aren truversenl. Aftor $n$ resume of the leating ornithological fentures of the region is presented min anotated list of the species secureal, 109 in nimber... Wits forel ut liberty to esall attention to some munscript alterutions male by the unthor in our copy. For Colurniculus passeriuns real Venotrichin albicollis; for Myiarchis. (rinilus, renil Tyranuss resticulis; for Archiluteo lughms. read A. ferm-

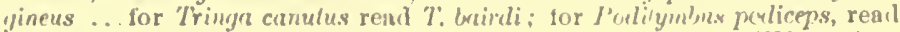
Policeps califomicus.. .- F C., Jull. Null. Uruilh. ('(u), Vol. VII, p. 113, April, 1882.

liatumus, Fraxk R.-Bright Feathers ol some North American Birds of Beanty. By Frank R. Rathbun. Illustrated with Drawings from Nature, aud earefully colored by hanl. Auburn, N. Y. Published by the Anthor, 1889. 4to. Purt I., pl. i-viii, 9 24, colored Plate and colored Vignette.

.... is an attractive piece of book making: the drawiog of the plate is passable, and the coloring is not more lighly exaggtrated than in many plates by authors of reputution for accuracy. The text more clearly betrays the haud of inexperience . The anthor is evidently not wanting in knowlerge of his subject; the fanlts of style he will doubtless he able to overcoure as the work proceeds. . -J. A. A., Bull. Nult. Ornith. Olut, Vol V., 1. 234, Uctober, 1850.

\section{Part II.}

Part II. of this work, .... is devoted to the lose-breasted Grosbeak (boniaphea ludoviciana.) The colver plate illustrates the adult male and fewale, but the sixteen quarto pages (pp. 25 40) of text leave the history of the species still unfinisher. In noticing Part I ... we were compelled to speak unfurorably of the literary execntion of the work, and regret that the present issue will not permit of an more favorable? notice.....J. A. A., J3 tl. Sull. Ornith. Chl, Vol. VI., pp). 172, 173, July, 1881 .

Ridgway, Robent.-Revisions of Nomenclature of certain North American Birds. By Robert Ridgway. Proc. $L$. ‥ Nut. Mus., Vol. III., 1881, pp. 1-16. Author's separntes issued March 27, 1880.

...Mr. Ridgway takes us a startin'-point Dr. Cones's "Check List" published in 1873 , and formally notices many of the changes from the nomenclature there adopted ...and proposes muny additional ones, the whole number ber receiviug attention amounting to upward of

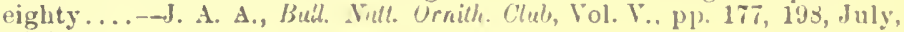
1880 .

Ridiway, Robert.-Nomenclature of North American Birds elifelly contained in the Tnited States National Musenm. By Robert Ridgway. Bull. U. S. Nat. Mus., No. 21. Published under the directron of the Smithsonim Institution. Wishington: Govermment Printing Office, 1S81. ovo., 1). 1-24.

....its publication marks nn epoch in North American ornithology.... The actual number of names ... in the present catalogue (1881). 
"924" ...the system is trinominal... The work....evinces the exereise of the ntmost care in its preparation.-J. A. A., Bull. Nutt. Urnith C'lub, Vol. VI., pp. 164-171, July, 1881.

Ridgway, Robert.--A Revised Catalogne of the Birds ascertained to occur in Illinois. By Robert Ridgway. Illinois State Laboratory of Natural History. Bulletin No.4. Bloomington, Ill., May, 1881. 8vo., pp. 161-208.

....based primarily upon the same anthor's "Catalogue of the I3irds ascertained to occur in Illinois," published.... in 1874. but adds : sl species....341 now enumerated, besides 11 adlitional varieties.... The species known to breed (213 in number) are distinguished by an asterisk.... The nomenclature is that of Mr. Iiilgway's recently nublished "Catalogne of North American Birds" . Illinois takes the lead among the States in respect $t$ n number of species of birls ...-J. A. A., Bull. Nutt. Ornith. Club, V'ol. VI, pp. 171, 172, July, 1881.

Roberts, Thomas S.-The Winter Birds of Minnesota. By Thomas S. Roberts. Ninth Ann. Rep. Geol. and Nat. Hist. Surv. Minn., for 1880, 1881, pp. 373-383.

....treats.... of 52 species known to occur in the State in winter ....the information given conveying a good iden of the bird-fauna at that season of the year....-E. C., Bull. Nutt. Ornith. Chtb, Vol. VII., p. 47, January, 1882 .

Seerofru, Henry. - Catalogue of the Birds in the British Museum. Vol. V. Catalogne of the Passeriformes, or Perching Birds in the British IInsenm. Cichlomorpha: Part II., containing the family Turdidw (Warblers and 'Thrushes). By Henry Seebohm. London, 1881. 8vo., pp. xvi, 426 , pll. xviii.

...this group is defined in MIr. Sharpe's scheme of classification, with limits rather different from those usually assigned to it ...we admire most heartily his [Mr. Seebohm's] thorough treatment of the subject in hand and the philosophic spirit in which he has approacherl his task....J. A. A., Bull. Nutt. Ornith. Club, Vol. VIII., pp. 99-104, April, 1883.

Sharpe, R. Bowderr. - Catalogue of the Birds in the British Musenm. Vol. VI. Catalogue of the Passeriformes, or Perching Birds, in the collection of the British MIuseum. Cichlomorphre: Part III. containing the first portion of the family 'Timelidie (Babbling Thrushes). By R. Bowdler Sharpe. London, I881. Svo., pp. xiii, 420, pll. xviii.

..... In respect to the classification followed in these volumes, Mr. Sharpe states that it is based on that of the late Professor sundevall. ....-J. A. A., Bull. Wiett. Ornith. C'lut,, Vol. VIII., 1'1. 104, 1C5, April, 1883.

Shlperdot, R. W.-Osteology of Speotyto cunicularia var. hypogaea. By R. W. Shufeldt, [First Lientenaut and] Assistant Surgeou, 
U. S. Army, Bull. U. S. lieol. and lieogr. Surr. of Terr., Vol. V., No. 1, Fol,runry 11, 1881, pp. 87-117, pll. i-iii.

SHuveldt, 12. W.-Osteology of Fremophilı ulpestris. liy li. W. Slunfeldt, [First Lientenant and] Assistunt Surgeon, U. S. Army. Bull. U. S. Geol. and Geogr. Surv. of T'rr., Vol. VI., No. 1, February 11, 1881, pp. 119-147, pl. iv.

As memoirs of lescriptive osteology these papers merit high praise, and may well be welcomed as valuable contributions in a little worked field.-.J. A. A., Brll. Null. Ornith. Club. Vol. VI., Pl. 109, 110, April, $1 \times 81$.

SHuffint, R. W.-Osteology of the North American Ietranida. By Dr. 12. W. Slinfelit, U. S. A. Bull. IT. S. Geol. and Georgr. surr. of Terr., Vol. VI., No. 2, pl. 309-35'(', pll. v-xiii.

... so fur as we know, the most complete of any [prper] on American birds of one group ..-J. Amory Jeffries, Jiult. Nill. Omith. Club, Vol. VII., pp. 44, 45, January, 1882.

Suvfent, R. W.-Osteology of Lauius ludovieimus excubitoroides By Dr. R. IV. Shufeldt, U. S. A. Bull. U. St. Geol. and Gieogr. Surv. of Terr., Vol. VI., No. 2, pp. 351 359, pl. xiv.

The description.... is short, concise, and may be summed up in the statement that the skeleton of this bird is strictly Passerine.--J. Amory Jeffiries, Bull. Nult. Ornith. Club, Vol. VII., p. 45, January, 1882.

Shufeldt, R. IV.-The Claw on the Index Digit of the Cathartidx. By R. W. Shufeldt, M.D. American Naluralist, November, 1881, pp. 906-9us.

...this paper contains such important errors, both in regard to structure of birds and the liternture of the subject thint some rectification seems necessary. Dr. Shufelit describes the claw at the end of the tirst finger of Culharista atralu ai a new dlscovery, considering that claws outside of the Ostrich groups have not hitherto been described, and also states that it is a point of distiuction between the Old and New World Vultures. . . the claw on the first finger is anything but an unknown object ...Thnt the cluw is absent in the Old World Vultures is alse an error if we may trust the high anthority of Nitzsch... as a rule the claws are much more conspicuous in young than in aduit birds.--J. Amory Jettries, Bull. Nitt. "1'nith. (tul, Vol. VII., 11). 46,47 , Jannary, 1882.

strearss, Winfrij A, and Coules, Eliotot - New Eugland Bird Life, being a Manual of New England Ornithology, reviserl and edited from the manuscript of Winfrid A. Stearns, Member of the Nuttall Ornithologieal Clnb, etc., by Dr. Elliott Cone's, L'. S. A., Nomber of the Aeademy, ete. Part I.-Oscines. Boston: Lee and Shepard, Publıshers. New York: Chmrles 'T'. Dillinghum. 18s1. Svo., pp. 3.24, numerous woodeuts.

.... we at length Lave a work on New Eughand Birds of which no ornithologist need feel ashamed... The muin body of the work com- 
prises two hundred and seventy pages and treats....the wholo order Uscines.... The claims of each species to be considerod a momber of tho New England Fum are criticully examined.... the design being to give a thoroughly reliable list of the Birch, with an account of the leading facts in the life-history of' each species. 'T'he plun of the work inclucles brief descriptions of the birds thenselves, embling one to identify any specimen ... l'o say that the book is exceedingly well-written would be loing it scaut justice. Dr. Coues s brilliaut talents in this respect are ulready well known, but we have perlaps never lud so struking a proot of them as is afforded by the present volume.......Mr. Stearus may be congratulated on his wise chosec of an editor.--W. B., Jull. Nutl. Urnith. club, Vol. VI., pp. 236-240, Uctober, 1881.

\section{2.}

Bicknell, Eugene Pintalid.-A Review of the Summer Birds of a part of The Catskill Mountaius, with prefatory remarks on the funnal and floral features of the region. By Etugene Pintard Bicknell. Transactions of the Linnaten Sociely of New York. Vol. I., pp. 113-168, December, 1882.

.... is based on observations made "during brief explorations of the more southern Catskills in three successive years, from June $b^{*}-15$, $1880 ; 12-18,1881 ; 24-27,1852 \ldots$ Twenty-tive of the total fifty-six pages are devoted to prefutory remarks....... Bickuell evidently has in penchant for the analysis and comparison of fauma, and his remarks in the present connection are decidedly interesting .. The list proper mcludes eighty-nine species and varieties. It is very fully annotated. ....-W. B., Bull. Nutl. Ornith. Club, Vol. VIII., p. 53, January, 1883.

Buasius, Rudouph.-V. Jahresbericht (1880) des Ausschlusses für Beobachtungs-stationen der Vögel Deutschlands. Juırual für Ornithologie, XXX Jahrg., Heft I, Jan., 1852, pp. 18-110.

'The fiftl annual report of the German observers for the year 1880 $\ldots$ is presented in the form of au annotated list of 280 species, compiled trom the reports of the variouz observers ... The notes relate to uesting of nuany of the species, as well as to their migrations... There are ... reports from no less than 36 stations, and the risumé of the observations taken forms a paper of great interest and value.-J. A. A., Bull. Lill. Ornith. Club, Vol. VIII., pp. 2229, 230, Uctober, 1883.

Brows, Nathan CuIfford.-A Catalogue of the Birds known to oceur in the vicinity of Portland, MIe. [etc.] By Nathan Clifford Brown. Proc. Portland Soc. Nat. Hist., Dec. t, 1852.

This excellent local list.... is stated to be prepared from notes sys. tematically taken during the past twelve years, und to coutain the names of scarcely any species which have not passel under the author's personal obsersation. Its reliability is therefore evillent. The number of species given is 251) ...The annotatious, though not extensive, wre to the point and seem judicionsly adapted to convey a litir jilea of the part each species plitys in the composition of the Avifumna. . - E.C., Bull. Null. Ornith. Club, Vol. VIII., 1)p. 112, 113, Aplel, 1803. 
Cuamemtan, Montage. - A Cutulugue of the Birils of New Brunswick, with brief notes relating to their migrations, hreeling, relative abundunce, etc. By Montagno Chumberlain. Bullelin of the Volural History sociely of Nein Brensurick. No. 1, 1). 23-68. l'ublished by the Society. Saint John, X. B., 1852.

..This paper ...comprises some forty-thre pages, which are di. videl into two sections; "Section A" being restricted to species which occur in St. Joln and King's Connties; while "Section I3" ('mbraces "species which have not heen observed in Saint John or King's Counties but which occur in other parts of the Provinee." The former division treats of a region to which the author has a vilontly pail special attention, and the text, being manly based on his personal observations or investigations, includes many interesting and several important notes and recorts... Section 13 is almost wholly rompiled .. IIr. Chamberlain's work, so far as it has gone, has evidently been done carefilly nud well.... in many respects it lacks the completeness that is desirable in a paper of its kind ....-W. B., Jull. Silt. omith. 'lul, Vol. VII., pp. $176,177, \mathrm{~J} 11 \mathrm{y}, 1882$.

Colmass, J. W.-Notes on the Habits and Metlods of Capture of varions species of Sea Birds that ocenr on the Fishing Banks off the Eastern Coast of North America, and which are used as bait for catching Codfish by New Englund Fishermen. By Capt. J. W. Collins. Ann. Rep. of the Comm. of Fish und Fisheries for 1882, pl. 311-338, pl. i.

... particularly welcome, not unly for the information they convey on these points [ser-birds capturerl and used us bait], but also respecting the relative abundance of the sea-birds met with on the fishing banks, their habits, seasons of ocenrrence, and murations... The species captured in largest numbers is the Grenter shenrwater (l'uffinus major)..... J. A. A., The Aut, Vol. I., 1']. 3\$6, 381, October, 1884.

Coves, Elliotr. - The Cones Check List of North American Birds, revised to date and entirely rewritten under lirection of the author, with a Dictionary of the Etymology, Orthography and Orthoëpy of the scientific names, the Concortance of previous lists, and a Catalogue of his Ornithological P'ublications. Boston : Estes and Lauriat. 1852. 1 vol. Royal Svo., pp. 165.

... it is much more than a cutalogne of North Aurrican bircls.... the erudition and scholarly resench involved in this undertaking must be apparent to the most casmal render. The practical value of the work is ecpully plain... The total number of species and varieties enumerated is eight hrudred and eighty-eight .... W. B., liull. Nuth. Omith. Ciul, Vol. VII., pp. 111, 112, April, 1882.

.... The purpose of the present 'Check List 'is, l'irst to present a complete list of the biris now known to inhnbit North Americe, north of Mexico and including Greenland ... Sicendly to take ench word... explain its lerivation, significance. and application, spell it correctly and indicate its pronunciation... Concerning the whole work we can say nothing stronger than that it is in every way worthy of its brillinnt and distinguished author, who has evidently male it one of his most 
mature and carefully studied efforts.....it fills a ficld of nsefulness peculiarly its own......-W, B., Bull. Sutt. Ornith. Club, Vol. VII., pp. 212-246, October, 1882.

Dubors, Alrionse. - De la Variabilité des Oiseanx du genre Loxia. Par M. Alph. Dubois, Conservateur au Mnsée royal d'listoire naturelle de Belgiqne. Extrait du Bulletin du Wusée royal d'histoire naturelle de Brlgique. Tome I. Oct., 1882.

.... These varieties, races, or subspecies, he holds to be the resnlt of the action of climate, food, or other "fortuitons canses" "1pon size and coloration, and state that his morploological sturlies have demonstrated that species are variable in proportion to the extent of their area of dispersion......J. A. A.. Bull. Nilt. Omith. Club, Vol. VIII., p. 170, July, 1883.

Dutcher, Wrlutay. - Is Not the Fish Crow (Corvus ossifragus Wilson) a winter as well as a summer resident at the northern limit of its range? By William Dutcher. Trensactions of the Linncean Society of New York. Vol. I., pp. 107-111, December, 1882.

.... is sbort, occupying less than three pages.... The evidence cited is apparently conclusive....-W. B., Bull. Fitl. Ornilh. Cinth, Vol. VIII., p. 5t, January, 1883.

Forbes, S. A.-The Regulative Action of Birds upon Insect Oscillations. By S. A. Forbes. Bull. No. 6, Illino is Strte Laboratory of Nat. Hist., Dec., 1882, pp. $1-31$.

Our best authority upon the insect fond of birds has continued his observations upon the sulject ...The paper is very carefully worked up to show how effectively birds may restore a disturbed balance of life ....We trust Professor Forbes will not desist from his good work. such exact data as these are just what is required for the solution of the general problem which is offered by the relations of the bird-world to agriculture.-E. C., Bull. Viett. Ornith. C'lub, Vol. VIII., pp. 105.107, April, 1883.

Gentry, Thomas G.-Nests and Eggs of the Birds of the United States [Pennsylvania]. 4to. 50 colored Plates. 1882.

Part I. of this new enterprise....has reached us .. The text of this number is meritorious, and the plates are not....-E. C., Bull. Wutt. Urnith. Club, Vol. V., p. 179, July, 1880.

Harve-Brown, John A., Cordeaux, John, and Newton, Alfred.Report of the Committee, consisting of Mr. J. A. Hurvie-Brown, Mr. John Cordeanx, and Professor Newton, appointed at Swansea "for the purpose of obtaining (with the consent of the Master and Brethren of the Trinity Honse, and of the Commissioners of Northern Lights) olservations on the Migration of Birds at Lighthonses and Lightships, and of reporting on the samc, at Fork, in 1891." London : Printed ly Spottiswoode and Co.. New-Street Square and Parliament Street. [1882.] Svo., Pu. ४. 
Hanve-Brow, Jom A., [ete.]-Report on the Migration of Birds in the Autumn of 1881. By John A. Jurvie-Brown, Mr. John Cor. demux, Mr. Philip M. C. Kermole, Mr. R. M. Barrington, aud Mr. A. G. More. Loulun : Printed by West, Newmun \& Co., 54, Hatton Garden. 1882, 850., pl. 101.

Horks. W, W. - I ist of Birds olserved at Ft. Berthold, D. 'T., during the month of September, 1841. 13: W. J. Hollnan, M.D. l'roc. IBoston sioc. Nul. Ilisl., Feb. 1, 188.2.

...the result of some observations mule during September, 1881 ...Fifty-seven species were identitied. 'The numotutions nr. usnally very brief ...A novel feature of the list is thut of the Indian names which are given for many of the common birts. W. W., Bull. Vutt. Omilh. Club, Vol. VIII., pp. 54, 55. Jannary. 145:3.

Inciensot, Ersest. - Birds'-Nesting: A Handbook of Instruetion in Gathering and Preserving the Nests und Lggs of Birds for the Purposes of Study. By Elnest Ingersoll. Salem, 1882.

This little book is intended for a guide to the lieginner. The hook may be summarized as a realable account of the various molt's of collecting hirds' eggs and nests 1 long acconnt of the varions paritphernalin for blowing and marking eggs is given... A list of unknown nests. contains fanlts of admission. thongh these are not numerous. ....-J. A. J., Bull. Putt. Omith. Club, Vol. VII., pp. 179, 180, Jnly, 188:.

Kxowltos, F. H.-A Revised List of the Birds of Brandon, Vt., and? vicinity. By F. H. Knowlton. The Brandon Uuion (newspaper), February 10, 1882.

This is a briefly annotated list of 149 species... . The chief interest of the list lies in its bearing upon the extent of the Alleghanian fauna in the Champlain valley..... Ir. Knowiton has recorded Wilson's Plover ....instead of Wilson's Snipe...C. F. B., Bull. Kilt. Omilh. Club, Vol. VII., pp. 113, 114, April, 1882.

Krokenisera, C. Fr. W. -Die Furbstoffe der Fedelu in Dessen vergleichend-physiologisehe Studien. Ton Dr. C. Fr. W. Krukenberg. II Reilıe, I Abth., 15s2, pp. 151, 171,

....the author describes the yellow pigment. Coriosulfurin, found in the tarsus of the birds of prey ....J. A. J.. Bull Sill. Gruith Clul, Vol. VII., pp. 177, 178, July, 1852.

Lawrexce, George N.-Description of a New Species of Swift of the genus Chatura, with Notes on two other littla-known Birds. By George N. Lawrenee. Amn. New York alere. Sci., Vol. II., No. 8, pp. 247, 248. March, 1842.

Lawhexce, George N. - Descriptions of New species of Birds from Yueatun, of the Families Columbida am Formicarida. By George X. Litwrence. Ann. Now Yor Acul. si.i., Vol. II., No. 9, p). 287, 288. Миу, 158:. 
Lawrence, Georee N.-Description of a New Species of Bird of the Family Cypselidie. By George N. Lawronce. Ann. New York Acad. Sci., Vol. II., No. 11, pp. 355, 356. December, 1882.

Lispex, Charles.-On the Domestication of some of our Wild Ducks. By Charles Linden. Bull. Buffalo soc. Nat. Sciences, Vol. IV., No. 2, pp. 33-39, 1882.

After brief reference to the various species of wild Ducks that formerly frequented Lake Clnutauqua, Western New York, which have now mostly become rare, Mr. Linden summarizes the results of systematic efforts continued for nearly thirty years by Mr. George Irwin th the ubove-named locality to domesticate several of the species. Then were the Mallard, Dusky Duck, Wood Duck, Ilue-winged Teal, anul American Swan. All of these bred freely and reared their young in con. finement....-J. A. A.. Bull. Nutt. Omith. Clul, V'ol. VIII., 1. 233, October, 1883.

Merriam, Chintox Harí. - The Vertebrates of the Adirondack Region, Northeastern New York. By Clinton Hart Merriam, M.D. [First Instalment.] Transactions of the Linnruan Society of New York. Vol. I., pp. 5-106, December, 1882.

....The present instalment of Dr. Merriam's paper does not extend to birds.... it in introductory portion has a direct bearing on everything to follow....As a contribution to our knowledge of the habits, food, times and manner of breeding, etc., of many of the northern mammals this paper is an important one ...-W. B., Biell. Yutt. Urnith. Club, Vol. VIII., pp. 50-53, January, 1883.

Mondex, J. A., and SAunders, W. E.-List of the Birds of Westeru Ontario. By J. A. Morden and IV. E. Śaubders. Canadion sportsman and Veturalist, Vol. II., Nos. 11 and 12, pp. 183-187, 192-194. November and December, 1882.

.... a briefly annotated list ... numbering 236 species ... a valuable addition to our knowledge of the distribution of Canadian birds.... J. A. A., The Auk, Vol. I., p. 85, January, 1881.

Reichexow, Axtos.-Conspectus Psittacorum. Systematische Ueber. sichte aller bekannten Papageienarten. Von Dr. Ant. Reichenow. 8vo., Berlin, 1582, pp. 234. (Sonderabdruck ans Journal fiir Ornithologie, XXIX Jahrg., 18s1, pp. 1-49, 113-177, 225-289, 337-398.)

The order Psittaci is divided into 9 families and 45 genera (including 27 subgenera); 444 species and subspecies are recognized.. ing 27 subgenera);
English and French, as well as German, vernacular names are given " for
It originally appedred in parts in the "Journal für Ornithologie" for 1881.-J. A. A., Bull. Vitt. Ornith. Club, Vol. VIII., p. 169, July, 1883.

Reichexow, Axtox.-Die Vägel der Zoologischen Gärten. Leitfaden zum Studium der Oruithologie mit besouderer Berücksichtigung der in Gefangenschaft gehaltenen Vïgel. Vin Handbuch tï 
Vogelwirthe. Von 1)r. Aut. Reichenow. In zwei Theilen. ['T'heil J.] Tseipzig, 1882, 8vo., pl?. xxx., 278.

Dr. Re(ichenow's handlook for bird-keepers is dexigned to furnish .... the means of rendily identifying knch species as are kept in zooilogienl gardens, purke, und aviuries, nul secms to be well whpted to that

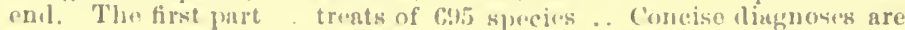

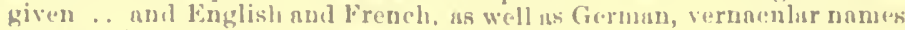
are supplied for tho species. As a pojulnr latml book for German renders . The work keens wortly of generons roumendition.- J. A. A.,

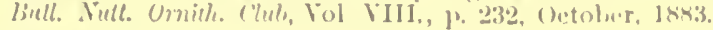

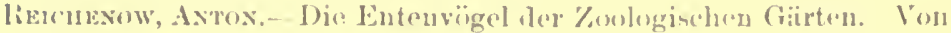
Ant. lieichenow. Ornithologiscleses Centrulblatt. VIJ Jahrg., Nos. 1-6. Jan.-May, 1s8:, p1) 1-5, 17.23, 35 40.

...enumerates the species of Iremellirwstres... uiving brief lling. noses of the species kept in zoülogical garilens .. - J. A. A., liull. . Vill. 1mith. Cluth, Vol. V111., 1).232, Oetober, 148:3.

likichexow, Axtox, and Sonalow, Henas.-Compendimm der nen beschriebenen Gattungen mul Arten. Von Anton Reichenow und Herman Schalow. Jomrual fïr Ornithologie, XXIX Jalıg., 18s1, pp. 70-102, 417-423; XXX Jahrg., 1882, pp. 111-121), 213-228.

'This convenient summary.... is still coutinued.... it gives transcripts of the originnl lingnoses, when such ure given, and in other cases mentions the types of the genera and the nllegen characteristion

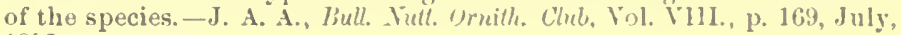
1883.

Ringwar, Roment.-On a Duck new to the North American Fauna. By Robert Ridgway. Proc. I. s.. Vut. Mus., Vol. IV., 18s2, Pr. 22-24. Anthor's separates issued April 13, 1851.

....Mr. Ridgway records an inmature male Rnfous-crested Duck (Fuligula rupina, Steph.) supposed to lave heen slot on Long Island Sonvil. In making the record $\mathbf{M r}$. Ridgway lakes oceasion to leseribe the species in its varions phuses of plumige, and alls a few critienl remarks on the generic synonomy of the gromp to which it belongs. J. A. A., Bull Vull. Omilh. Clul, V̌ol. VJ., p. 173, July, 1881.

lingway, Ronert. - On Amazilia yucataneusis (Cabot) and A. cerriuiventris, Gould. By Robert Rillgway. I'roc. l'. ‘. Sil. Mus, Vol. IV., 188:, pp. 25, 26. Author's separntes issued April 13, 1881.

... Comparative dingnoses are given of the two species, with some remarks respecting their distribution.- J. A. A., Jull. Vitl. Irrith. Club, vol. VI., pp. $173,174, . J 11 y, 1881$.

Ridgwa, Ronert. - A Review of tho genus Conturus, Swansom. By

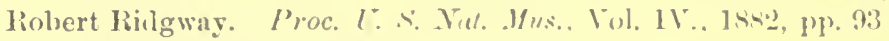
119. Anthor's separates issued June '2, 1kst.

This revision is lused on an examination of 227 specinens, representing 12 of the 14 forms considered as sufleiently distinet for rong. 
nition.... Each form recognized is described in detail, and the whole subject is treated with Mr. Ridgway's usual care and completeness.-J. A. A., Bull. Nutt. Ornith. Club, Vol. VIII., p. 114, April, 1883.

Ridgway, Ronent. - List of Species of Middle and South American Birds not contained in the United States National Museum. By Robert Ridgway. Proc. U. s.. Nat. Mus., Tol. IV., 1882, pp. 165203. Author's separates issued Ang. 11 and Nov. 18, 1881. .... The species wholly unrepresented are very few .....J. A. A., Bull. Nutt. Ornith. Clul, Vol. VIII., 1) 170, July, 1883.

Ridiwar, Ronent. - List of Special Desiderata among North American Birds. By Robert Ridgway. Proc. U. s. Nut. Mus., Tol. IV., 1882, pp. 2(17-223. Author's separates issued Nov. 18, 1881.

Ringway, Robert.-Catalogue of Old World Birls in the Inited States National Musenm. By Robert Ridgway. Proc. U. S. Nat. Mus., Vol IV., 1882, pp. 317-333. Author's separates issued March 8, 1882.

.... The numeration and classification adopted is that of Gray's well-known "Hand-list."-J. A. A., Bull. Nult. Ornith. Clul, Vol. V'III.. p. 231, October, I883.

Ridgway, Robert.-Notes on some Costa Rican Birds. By Robert Ridgway. Proc. U. S. Nit. Mus., Vol. IV., 1882, pp. 333-337. Antlıor's separates issued March 10, 1882.

RidGway, Robert.-Description of a new Flyeateher and a supposed new Petrel from the Sandwich Islands. By Robert Ridgway. Proc. U. S. Nat. Mus., Tol. IV., 1882, pp. 337, 338. Autlior's separates issued Mareh 29, 1882.

Ridiway, Robert.--Description of suew Owl from Porto Rico. 'By Robert Ridgway. Proc. U. S', Vat. Mus., Vol. IV., 1882, pp. 366371. Author's separates issued April 6, 1882.

Ridaway, Robert.-Description of two new Thrushes from the United States. By Robert Ridgway, Proc. U. S. Nat. Mus., Vol, IV, 1882, pp. 374-379. Author's separates issued April 6, 1882.

Rivgway, Robert. - On two Recent Additions to the North American Bird Fauna, by L. Belding. By Robert Ridgway. Proc. U. S. Nat. Mus., Vol. IV., 1852, pp. 414, 415. Author's separates issued April 24, 1882.

In numerous papers published in the "Proceedings" of the $\mathrm{Na}$ tional Mnsenm for 1881 and 1882, Mr. Ridgway has deseribed a considerable number of new species and races of birds and several new genera, chiefly from North and Middle America. 'They alsn contain Dotes on a few other hitherto little known species....- J. A. A., Lull. Sutt. Ornith. Club, Vol, VIII., 1'p. 168, 16!, Jnly, 1883. 
Saunders, Howand.-On some Iaride from the coasts of Peru and Chili, colleeted hy Capt. Alhert H. Markham, R.N., with Remarks on the Geogruphienl Distribntion of the (irouj) in the Pneitie. By Hownrd Saunders, F.L.S., F.Z.S. P'rec. Yonl. Sisc. of London, June 6,1882 , p). 520-530; with colores plate: of Xemu furcatum ulult and young.

... Fifteen species are represented: mung these is a specimen (the third one known) of leme furculum, now rediseovered ufter an interval of torty years' fruitless seareh Mr. Sumblers is nne of the few scientitic writers who ponsess the happy faculty of making a technicul treatise interesting to the average realer. The present paper. . has a direet value to tho student of North Americun ornithology, for much of its subject-matter... relates to species which are inclucled in the North

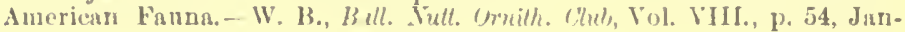
nary, 1883.

SHCFEnt, R. W. - Contributions to the Anutomy of Birds. By R. W. Shufellt, M.D. [etc.] Author's edition, extracted (in advunce) from the Twelfth Annunl Report of the late U. S. Geological and Geographical Survey of the Territories (Hayclen's). Washington : Government Printing Oflice, October 14, 1882. 8vo., title and pl. 59:3 806, pll. i-xxiv., many woołcuts in text.

It includes chapters on the osteology of siperlyto cun icularia hypongera, Ei emophil alpestris, the North American Tetromidle nnd the (athartide. These subjects have been already treated by Dr. Shufeldt in previous papers.... : but its subject-matter has been largely, if not entirely rewritten, and some unfortmnte errors ... corrected... The paper on the Cathortide with its ncompanvan plates, is entirely new matter. -W. B., Bull. Vult. (Mmilh. Clul, Vol. Vill., p. 56, Jannary, 1883.

Under this title a meritorious and very pronising ornithotomist has brought together the greater part of what he has thus far accom. plished in the way of nvian anatomy... It wonld scarcely be fair, however, to judge their resplenrunce by their original eharacter, all of them having been carefully revised und to some extent rewritten... The text is a faithful and on the whole an necurate description of the objects under designation, and the fidelity with which the plntes are executed is most commendable ...-W. C., Binll. Nill. Imill, ('tul, Vol. Vill. pp. 166-168, July, 1883.

Stejneqer, Leoshand. Deseription of two new Races of Myadestes obscurus Lafr. By Leonhard Stejneger. I'roc. C. S. Nul. Mus., Vol. IV., 1882, pp. 371-374. Author's separites issued April 6, 188.2 .

...M. wbecurus var. oecidentelis, from the highlands of Sonthern IIexico and Guatemala, an't $\%$. whenrus vir. insuluris, trom the 'lres Marias lslands. - J. A. A., biell. Wult. Irvill. I\%ul, Vol. V1ll., p. 170, July, 1883.

Wuenton, J. M. - Report on the Birds uf Ohio. By J. M. Whenton, M.D. Report of the fieolugical sitreen! of (Jhie, Vol. IV., pt. i., 
pp. 188-628. Columbus, Olio: Nevins of Myers, State Printers. 8 vo. 1882.

.... a trentise on the ornithology of the State so extensive and so systematic that the time its preparation has occupied seems justified if not absolutely required .. Dr. Wheaton's report unst at ince take place at the head of S'ate Fumas, so fur as ornithology is eoncerned ... Ohioans have here, in fuct, a correct history and deseription of their 300 birds, systematically arrunged and classified, with diagnoses of the genera and higher groups, a considerable synonomy of each spuecies with special reference to state literature, and a local bibliography... this volume of some 450 pages is no slight nor uneertain aldition to onr ornithological literature....-E. C., Bull. Iull. Grnilh. Clul, Vol. VIII., pp. $110-112, A$ pril, 1883.

White, Geolge R., and Scotr, W. L.-Commentary on the BirdFam of the Vicinity of Ottawa. By Geo. R. White and W. L. Scott. Report of Ornithological and Ö̈logical Branch, Troms. Ottrwa Field Naturalists' Chul, No. 3, pp. 26-34, and Appendix.

The list is briefly annotated, and contains 169 species .. we are astounded to see in the list Ifarproluynchus cirereus!' I'arus rufescens.' Vireo pusiltus! Glincidium passerinum var. cutifornicum! 'This of conrse puts the whole affair nnder a cloud as an incompetent and doubthess pretty nearly worthless perfornance. - E. C., Bull. Tutt. Ornith. C'lut, Vol. VIII., p. 55, January, 1883.

[ ...The authors ...hal no opportunity to correct the proof.sheets ....Edd.] Bull. Nutt. Ornith. c'ub, Vol. VIII., pp. 115, 116, April, 1883.

1883.

Beckhay, Charles Wickliffe. - A List of the Birds of Bardstown, Nelsou County, Kentucky. By Charles Wickliffe Beckham. Journ. Cincinnati Soc. Nat. Hist., Vol. VI., pp. 136-147, July, 1883.

....the first paper on the birds of Kentucky, as such, which has yet appeared, and relating mainly to the birds of the immediate vicinity of Barlstown, ". . . no species has been admitted on any but the best of evidence; out of the one hundred and sixty-seven enumerated, the writer is himself responsibie for all but eight of them "...The list is briefly annotated . is well printed, and evidently carefully prepared ....-J. A. A., Bull. Nutt. Omith. (7ub, Vol. VIII., pp. 227, 228, October, 1883.

Cооке, W. W.-Mississippi Valley Migration. By W. W. Cooke. Ornithologist and Oölogist, Vol. VIII., Nos. 4-7, April-July, 1883, pp. 25-27, 33, 34, 41, 42, 49-53.

....Mr. Cooke's scheme contemplates a large number of observing stations ...he appears to have correspondents at 44 stations ...his matter is pertinent and in most cases well arranged; while his sum. maries respecting the movements of particular species, as given in his later papers, show at a glance what are the results attained.--J. A. A. B cll. Nult. Ornith. Club, Vol. VIII., pp. 230, 23I, October, 1nষ3. 
Conke, IV. W.--13irnl Migration in the Mississippi Valley. By W. W. Cooke. Forest ant stream, Vol. XIX., Nos. 15, 1i, 20, pp. 283, 28.1, 306, 38.4, November ! and 16, and 1)ecembor 14, 1883.

Comy, Chandes B. - Beantiful and Curions Birds of the World. By Charles 13. Cory. Published by the Authur. Part IV. Elephant folio. 'Three P'lutes, with 'Text.

- contains plates of Pseudogryplens culifurniumus ...; Cumplodermus

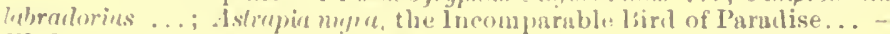
W. 13., Bull. Vitt. Writh. (ilub, Vol. VIIl., Wl. 55, 51, Jannary, 1883.

Cons, Chandes B.-Beantiful and Cnrions Birds of the World. By Charles 13. Cory. I'ublished by the Author. Fart V. Elephant folio. 'Three Plates, with Text.

... has jllustrations of Epimaclens mrumus, the Magniticent Bird of l'aralise, Eimuchus elliolti, Eslliott's Biri of l'arailise and Pluvionus rygptius. the crocodile Bird of the Nile......W. 13., Bull. Xull. 1)rnilh. Club, Vol. VIII., pp. 55, 56, Junnary, 1 s83.

Conx, Ghinges B. - Beantiful and Curions Birds of the World. 13y Charles 13. Cory. Published by the Author. Parts VI. and VII. Elephant folio.

....completes the work, which consists of twenty plates, with accompanying text... The plates.. are superb illustratuns of some of the most striking forms of bird-life... W. W. 13., The Auk, Vol. 1., p. 81, Jannary, 1884 .

Coles, Elhotr. - A Hearing of Birds' Fars. Jy Elliott Cones. science, Yol. II., Yos, 34, 38, and 39, pp. 422-424, 552-55t, 586589, Sept. 28, Oct. 26, Nov. 2, 18\$3, tigg. 9.

....A clear and detailed acconnt of the meshanism of the ear in birls, taking the human ear as the chief basis of compatrison ......J. A. A., The Auk, Vol. I., 1. 18:, A pril, 1s'st.

Cozes, Elurotr, and Plisiss, D. Wenster.- linlletin of the United Stutes National Museum, No. 26. Avifana C lumbiana : being a list of Birds ascertained to inlazhit the District of Columbia, with the times of arrivial anil departure of such as are nonresictents, and brief notices of habits, ete. The Second Edition, revised to date and entirely rewritten. By EHliott Cones, M.D., Ph.D., Professor of Anatomy in the Nittional Medical College, etc., and D. Webster Prentiss, A. M., M.1)., P'rofessor of Materia Merlica and Therapentics in the Sittional Melical College, etc. Washington: (roverument Printing Office. 1 tr.3. Svo., pp. 133, 100) wooleuts, froutispiece, and 4 folited maps.

The title of this interisting lirochure, althongh explicit. fails to fuily imply the seope of the work, I fiage's of which ure ilevoted to the 'Literature of the suljeet, 17 to the Locatom amb lopeglaplyy rt 
District,' 5 to the 'General Clanrater of the Avifanna.' 78 to the. 'Annotated List of the Birls,' 8 to a 'Summary and Recnpitnlation,' and :3 to the 'Gane Laws of the District'... The original ' List'... pul. lished in 1862 , contrined 226 species ... The adrlitions marle in the twenty-two years which liave intervened number 23 .. The smbject in general is trented not only with grent fnlness, bnt is very attractively set forth, and in general plan forms an excellent morlel of what a fanmi] list should be ...-J. A. A., The Auk, Vol. I., p. 386, October, $18 \$ 4$.

Gadow, Hans. - Catalogue of the Jirds in the British Musenu. Vol. VIII. Catalogue of the Passeriformes, or Perching Birds. Cichlomorphe : eontaining the Families Pardice and Laniidar. (Titnice and Shrikes), and Certhiomorphe (Creepers and Nuthatclies). 1iy Hans Gadow, Ph.D. London : Printed by order of the 'T'ustees. 1883. 8vo., pp. i-xiii., 1-386, pll. i-ix., and woodents in the text.

....Dr. Gadow's volume opens with the Paride (including the Regnlidx auct.), of which 10 genera and 82 species are recognized ....The Laniida embrace five subfamilies.... The family Certhirla includes the Nuthatches as well as the Tree-Creepers ... In general, Dr. Gadow inclines to the recognition of comprehensive groups, from families downward. His reduction in genera and speeies from the hitherto current status is very marked.... In method of execution, the present volume is strictl in accord with its predecessors, and is neither less valuable nor less welcome.-J. A. A., The Auk, Vol. I., pp. 279-281, July, 1884.

Gild, Theodone.-Record of Seientifie Progress for 1881. '/oölogy. By 'Theodore Gill. Smithsonian Report, 1881 (1883), pp. 408498. Birds, pp. 481-490.

... a partial bibliography of noteworthy papers and works, and a synopsis of about half-a-dozen memoirs...-J. A. A, The Auk, Tol. I., p. 34 , January, 1884.

Goss, N. S. - A Catalogue of the Birds of Kansas. By N. S. Goss. Published under the direction of the Executive Conncil. Topeka, Kansas: Kansas Publishing House, 1883. 8vo., pp. iv., 34.

... a carefully annotated list of the birds of the State. prepared at the request and under the direction of the State Executive Conncil ... very few species are given on other anthority than his own observations ....the list includes 320 species and races, 161 of which are marked as known to breed. The annotations are brief but pertinent... the list ....attains in general a high grade of excellenee. ..-J. A. A., Jiull. Nutt. Ornith. Club, Vol. TIII,, p. 227, October, 1883.

Jeffries, J. Ayrory.-The Epidermal System of Birds. By J. Amory Jeffries. Proc. Boston Soc. Nit. Hist., Tol. XXII., pp. 203-240, pll, iv-vi. Dec., 1883.

...reports the results of his stulies of the epiclermal appendactes in birds, with reference to their structure, development, and homologies....-J. A. A., The Auk, Vol. I., p]. 182, 183, April. 1881. 
Kiner, F. H. - Eeonomic Rolations of Wisconsm Birds. By F. H. King. Wisconsin Cieulogical siurpey, Vol. I., chip. xi., pu.441-610, ligg. 103-144. Royal 8vo.

....l'rof king's tieli-work.... was crmmenced in 1873 , and is apparently only just conelnded - his attention during this long period being stendily and rigidly directed to discovering whint and how nueb food Wisconsin birds ent ... The fucts recordel .. were obtuined from an exminination of the contents of over 1.80$)($ hirls ... The Introrluction c!oses with " " Temporary Classification of Wisconsin Birls on an economie basis" . . The botly of the report is primarily of the nature of an ordinary "local list" for the Stute of Wisconsin, giving in systematic order 295 species... The report is wall written, giving in many chses extended biographies. . The numerons woodcuts are chietly trken from Buird. Brewer, and lidgway.--E. C., Bull. Null. Ornith. Chib, Vol. ViII., pp. $107-110$, April, 1883 .

Lawrexce, Georae N.-Descriptions of New Species of Birds of the Genera Chrysotis, Formicivora, and Spermophila. By George N. Lawrence. Anu. New York Acal. Sici., Vol. II., 1852, No. 12, pp. 381-383. Issued June, 1883.

The species bere described are: 1. Chrysolis conifrons....2. Fomniciurra griseigula.... and 3. Spermuphila preren ...-J. A. A., The Auk, Vol. I., p. 387, October, 1884.

Mortox, Thomas, and Adxis, Charles Fraxcis, Jr.-The New Euglish Cauan of Thomas Morcon. With Introluctory Matter and Notes by Charles Francis Adams, Jr. Boston: Published by the Prince Society. 1883. Sm.4to., pp. vi, 381.-Chap. IV. Of Birds and Fethered Fowles, pp. 189-199. With notes by William Brewster and the Editor.

....reprinting Thomas Jorton's "New English Canan" (published originally in 1637), with editorial notes ... The technical notes on the birls, by JIr. Brewster, form an excellent comnentary on the species mentioned by Jorton ...MLorton's Niw English Canatn, as thu; almirably edited, includes nearly everything of interest bearing upon the natural history of New England contained in these early aceounts of New England ... The work is limited to 250 copies, and in typography and paper is a noteworthy specimen of hook-1naking. J. A. A., The Auk, Vol. I., p. 81, January, 1884.

Nelsos, E. W.-Birds of Jering Sea and the Aretic Ocean. By E. W. Nelson. Cruise of the Reveune-steamer Gorwiu in Alaska and the N. W. Aretic Ocenn in 1881. Notes and Memoranda: Medieal und Anthropological; Botunical; Ornithological. Washington : Gorernment Printing Office. 1853. 1 vol., 4to., pl. 55, 56, 56 a-f, 57-118; with 4 colored plates.

...It is a pity that so valuable and interesting a treatise as this of Ir. Nelson's should not have been uore carefully priutel ... After some pages eoncisely descriptive of the region anit its aritimn, the anthor proceeds to treat, in more or less detml, no fewer than $192 \mathrm{spe}$. cies of birds, North American with few exceptious.... it is illustrated 
with four colorer] plates, exccuted by Mr. [Robert] Ridgway, representing Motacilla oculariv, Lanius cristatus, Eurynorhynehus pymnests and (ire. ronia pusilla ...-E. U., The Auk, Vol. I., pp. T6-81, January, 1884.

Rrdaway, Robert.-A Review of the American Crosslills (Loxir) of the L. curvirostra type. By Rohert Ridgway. P'roc. Biol. Sioc. of Washington, Vol. II., 1883, yp. 81-10\%.

....He recognizes three races of Amorican IRed Crossbills, one of which ( $L$. cuvirostra bentirei) is described as new ... In North Amerien the Red Crossbills decrease in size from the north southwarl . 'Th<re are also remarks on other races of lied Crossbills, particularly the $l_{\text {. }}$ curvirostra and L. pityusiltucus of Europe.-J. A. A., The Auk, Vol. II., pp. 206, 207, A pril, 1885.

Ridgway, Robert-Description of Several new liaces of Ameriean Birds. By Robert Ridgway. Proc. U. N. Nut. Mus., Vol. V., 1883, pp. 9-15. Author's separates issued June 5, 1882.

RIDGway, Robert-On the genera Harporlyyuchus, Calnnis, and Methriopterus, Reichenbach, with a deseription of a new genus of Miminx. By Robert Ridgway. Proc. U. S. Nut. Mus., Vol. V., 1883, pp. 43-46. Anthor's separates issued June 5, 1882.

Ridgway, Roberr-Critical Remarks on the Tree-creepers (Certhia) of Europe and North America. By Robert Ridgway. Proc. $U$. S. Nat. Mus., Vol. V., 1853, pp. 111-116. Author's separates issued July 8, 1882.

....he proceeds to characterize seven races as susceptible of definition, three of which are for the first time named....-J. A. A., Bull. Nutt. Ornith. Club, Vol. VIII., p. 113, April, 1853.

RIDGWay, RoBert-Description of some new Nurth American Birds. By Robert Ridgway. Proc. U. s.. Nat. Wus., Yol. V., 1883, pp. 343-346. Author's separates issued Sept. 5, 1882.

RIDGWAY, Roneri-Catalogue of a Collection of Birls male in the Interior of Costa Riea, by MIr. C. C. Nutting. By Robert Ridgway. Proc. U. S. Nat. Mus., Vol. V., 1883, pp. 493-502. Author's separates issued Feb. 28, 1883.

The collection reported upon was made partly at Volcan de Irazí and partly at San José.... There are brief tield-notes by the collector, and technical notes on a few species by Mr. IRidgway.-J. A. A., The Auk, Vol. I., p. 84, January, 1884.

Ridgway, Robert. -Description of a New Warbler, from the Island of Santa Lucia, West Indies. By Robert Ridgway. Proc. U. s. Nut. Mus., Vol. V., 1883, 11. 525, 526. Author's separates issued March 21, 1883.

IIr. Ridgway separates as a new subspceies the Warbler from Santa 
I, lein, W. 1., hitherto known as Dendroict adduider nuder the name of

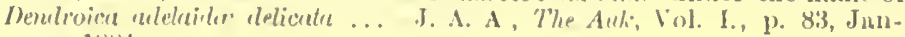
uury, 1884 .

Runway, Ronent, Description of a supposed New Plover, from Chili. By Robert Riclgway. Proc. U. s'. Nul. Mus., Vol. V., 185:3, pp. 526, 527. Author's separates issuerl Murcli 21, 1883.

(Ejialites albidipeclus, sp. nov.) hased on a single exmmple from Chili. J. A. A., The Auk, Vol. I., p. 83, Junuary, 1881.

Ridaway, Ronent.-On the Genns Tuntalns, Linu., and its allies. By Robert Ridgway. Proc. U. S. Nul. Mus., Vol. V., 1883, pp. 550, 551. Author's separutes issued Mareh 21, 1883.

The genus Tontulus Linn., is restricted to T. loculutor, ....... A. A., The Avk, Vol. I., p. 83, Jaumary, 1884.

Ridaway, Robekt.-Description of a New Petrel from Alaska. By Robert Riulgway. Proc. U. S. Nut. Mus., Vol. V., 1883, pp. 656658. Anthor's separates issued June 26, 1883.

...((Estrelat' fisheri, sp. nov.) from Alaska, a species most nenrly allied to $F$ : defllipirena Mr. Ridgway is inclined to refer also the Petrel taken in Livingston Connty, N. Y., identified by Mr. Brewster .... as $E$. gularis, to $C$. fishtri.-J. A. A., The Auk, Vol. I., p. 83, January, $188 t$.

Ridawar, Ronert.-Notes npon some Rare Species of Neotropical Birds. By Robert Ridgway, Curator Department of Birds, United States National Mnseum. The Ibis, October, 1883, pp. 399-401.

The species considered are Ilarponlunchus oscellutus Scl., Pyrangre erythrocephatus (Sw.), Zonotrichia quinquestrinta Scl. at Salv., Contopus ochraceus scl. it Salv., and Panyptita cayennensis (Gm.), about which there are brief remarks respecting their aftinities ....J. A. A., The Auk, Vol. I., pp. 386, 387, October, 1884.

Skenona, Henm.-A History of British Birds, with colored Illnstrations of their Eggs. By Henry Seebohm. Loudon: Published for the anthor by R. H. Porter, 6 'Teuterden Street, W., and Du1 u \& Co., Soho Square, W. Royal sro., Vol. I., 1883, pp. xxiv., 613, pll. 20 ; Vol. II., (Part 1, 1883, Part 2, 188t) pp. xxxiv., 600, 1)!1. 22.

....The typogruphical execution of the work is excellent, und the plates are entitled to high pruse... In respect to nomenclature und classitication Mr. Seebohm is conservative to 12 degree appronching eccentricity, but in respect to the general sulject his virws are liberal, philcsophic, and progressive... As regurds classification Mr. Seehohm seems inclined to ignore all recent progress, .... In respect to the 'vex"d question of nomenclature' he has throughout his work "set the Rules of the British Association at definuce..." His punacea for the evil 
is... the adoption of an 'auctorum piurimorum' rule;... For sub. species be adopts what nay be termed a Seebohmian system of trinomials first instituted by him in lis British Mnsenm Catalogue of the Tur. didie ...As Mr. Seebohm says : "The real histury of a bird is its lifthistory. The deepest interest attaches to every thing that reveals the little mind, however feebly it may be developed, which lies behind the feathers. The habits of the birl during the breeding senson, at the two periods of migration. and in winter ; its mode of flight and of progression on the ground, in the trees, or on the water ; its song and its various call-and alarm-notes ; its food and ite nuans of procuring it at different seasons of the yenr; its migrations, the dates of arrival and departure, routes it chooses, and the winter quarter's it selects; and abore all, every particnlar respecting its breeding, when it begins to build its nest, the materials it uses for the purpose, the number of eggs it lays, the variations in their color, size and shape, all these particulars are the real history of a bird; and in the acconnt of each species of British birls I endeavor to give us many of them as possible.". ...Mr. Seelolim's work abounds in passages which invite comment ...-J. A. A., The Auk, Vol. II, pp. 88-91, Jannary, 1885.

Sharpe, R. Bowdere-Catalogne of the Birds in the British Musenm. Vol. VII. Cutalogne of the Passeriformes, or Perching Birds. Cichlonorpluse: Part IV., containing the concluding portion of the Family 'I imelijdae (Babbling Thrushes). By R. Bowdler Sharpe. London: Printed by order of the Trustees. 1883. 8vo., pp. i-xvi., 1-698, pll. i-xv., and numerons wrodents in the text.

The family Timelider. an account of which was commenced in the preceding volume [Vol. VI.], is here [Vol. VII.] completed, with the enumeration and description of 657 species.... while many ornithologists may not agree with the anthor in his allocation of certain forms, none, we fancy, can feel otherwise than deeply gratefnl to him for the very useful monograph he has placed at their disposal.-J.A.A., The Auk, Vol. I., pp. 278,279 , July, 1084.

Sinth, Everett. - The 13irds of Maine. With annotations of their comparative abnndance, dates of migration, breeding habits, etc. By Everett Smith. Forest and Stream, Vol. XIX., Nos. 22-26; Vol. XX., Nos. 1-7 and 10-13.

.... Passing to water birds it is gratifying to finc a better quality of work. Mr. Smith is evidently at home here, and proofs of the general accuracy of his information and judgement are numerous and unmistakable....It is too good a paper to be wholly condemned, too fanlty a one to be generously praised .. Its nuthor... bas become almost an ornjthologist....-W. B., Bull. Iult. Ornith. (7ub, Vol. VIII., pp. 164-166, July, 1883.

Stearxs, W. A.-Notes on the Natural History of Labrador. By W. A. Stearns. Proc. L. S. Nat. Mus., Vol. VI., 1883, pp. 111-137. Author's separates issued July 27 to Sept. $20,1883$.

These "Notes" relate only in part to birds, which occnpy pp. 116123. The list of birds numbers 111 species. and is briefly annotated... -J. A. A., The Auk, Vol. I, p. 284 July, 1884. 


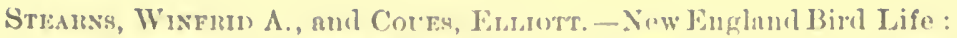
leing n Mnnun] of New England ornithology. Liw vised and edited from the munseript of Winfrid A. Stemms, Menulere of the Nuttall Ornithological Clul, ete. By lillintt ('mun, Member of the Acmlemy, ete. Purt II. Non-oscine l'nsseres, Biris of P'rey.

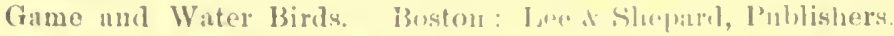

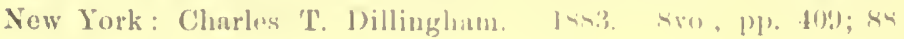
woodents.

...Dr. Comes hus gone bravely on with the tiank of "wliting" Mr. Stearns's mannseript, and the finished work, now onplets in two

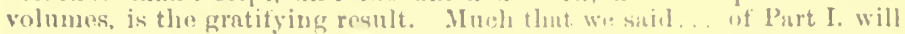

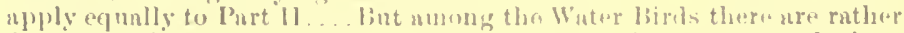
frequent evidences of hasty, and often positively insorract ennclusions

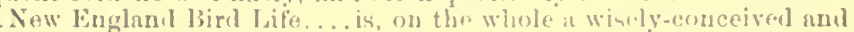
ndmirally-executed bogk-luy the best, in firct, which bus been so fin

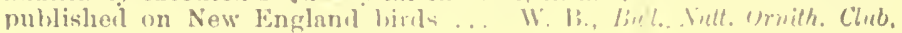
Vol. VIII., 1). 161-164. July, 18\$3.

Strasegel, Leovilamp, - Symopsis of the Wost Imlian Myialestes.

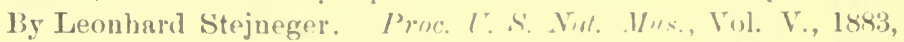
1p. 15-27, pl. ii. Anthol's separates issuel June j, 1842.

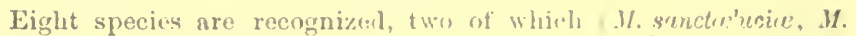
dominicanus) are lescribed as new.-J. A. A., lint'. Nut!. Ornith. Clut, Vol. V'III., 1). 170, July, 185:3.

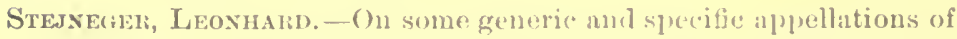
North American Birds. By I feonlarel stejueger. Proc. U. S. Nut. Mus., Vol. V., 1893, pl). 28 1:3. Author's sprarates issued June 5, 1882.

Proposing to nse "tlue ollest availal,l. nalu* in "sery case" the anthor shows that many of onl corrent nitmes must give wity if the "intlexible law of priority" is to be olservol. For turselsus we be. lieve that the surest way ont of the momenclatmral aliticultifs l hat beset us is to be found in some such simple rule us thic . . Fill such as paper as this makes us wish ... thut some comnterurtir. . statute of limitation" eould come into operation ... Stejueger s prouts seem to be well taken in the main: and... we presume the rentribtime amb smbstitntions he proposes are avaluble. if not in

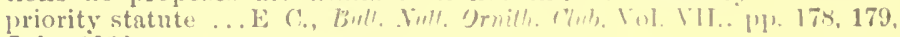
July, 1882.

Straseger, Leonhard,- Ontlines of a Monugraph of tha Cygninat. By Leonhard Stejneger. I're. I'. ‥ Virt. Wus. Vol. V., 1883,

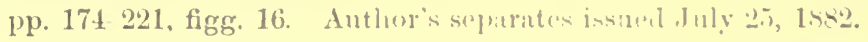

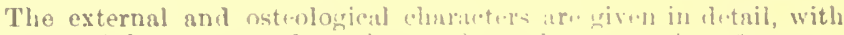

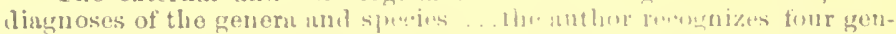

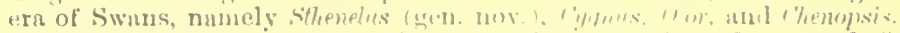
The two North Amerienn species are aninnel to the. J. A. A.. lindi.

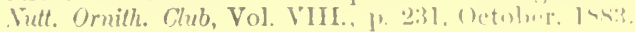


Stejneger, Leonhard. - Remarks on the Systematic Arrangement of the Amorican Turdidie. By Leonhard Stejneger. Proc. U. S. Nut. Mus., Vol. V., 1883, pp. 449-483, with numerous cuts. Author's separates issued February 13, 1883.

....Dr. Stejneger's synopsis of the family extends only to the genera and higher groups us represented in America. The generic synonomy is fully given, and the generic diagnoses are supplemented by general remarks and figures illustrative of the principal generic characters. -J. A. A., The Auk, Vol. I., pp. 181, 182, April, 1884.

'Towssend, Charles H. - Notes on the Birds of Westmoreland County, Penua. By Charles H. Townsend. Proc. Acarl. Nat. Sci. Philadelphiı, 1883, pp. 59-68.

"The species enumerated represent perlinjs not more than twothirds of the actual birds of Westmoreland Connty" .... The list, num. bering 136 species, is rather too sparingly annotated ...but we are led to hope that this may be the forcrunner of a fuller report.-J. A. A., The Auk. Vol. I, p. 184, April, 1884.

Tuelon, James A. - List of Birds observed near Bradford, Pa., by James A. Tuelon. Quarterly Jour. Boston Zoöl. Soc., Vol. IV., January, 1883, pp. \&-11.

As the whole number is only 77 , withont exception very common and well-known species, and as the annotations are of no special consequence, the reason why the list is printed is not evident.-E. C., Bull. Nutt. Ornith. Club, Vol. VIII., p. 171, July, 1883.

Turner, Lucien M. - On Lagopus mutus, Leach, and its Allies. By Lucien M. Tumer. Proc. U. S. Nat. Mus., Vol. V., 1883, pp. 225-233. Author's separates issued July 29, 1882.

The author believes....that the European birds inutus and a'pinus constitute " but a single species having the name Lrgopus mutus Leach, while the American bird ...to be called Ligopus mutus ruprostris (Gm.) Ridg. Four races are recognized ... Detailed deseriptions and measurenents are given of a considerable number of specimens of each race. -J. A. A., Bull. Nutl. Ornith. Ctub, Vol. VIII., p. 232, October, 1883.

Whluard, S. W.-Migration and Distribution of North American Birds in Brown and Ontagamie Counties. By S. W. Willard. De Pere, Wis., 1883, 8vo., pp. 20.

....The paper gives evidence of careful observation, and is a valuable contribution to our knowledge of the manner of oceurrence and movements of the birds of the area in question.-J. A. A., The Auk, Vol. II., pp. 289, 290, July, 1885.

Nóre. Publication of Purt II. of this paper is deferred to a succeeding number of these 'Abstracts.' 



.

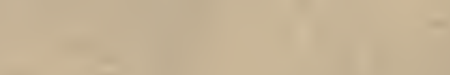

a 


\section{UNIVERSITY OF CALIFORNIA LIBRARY \\ Los Angeles}

This book is DUE on the last date stamped below.
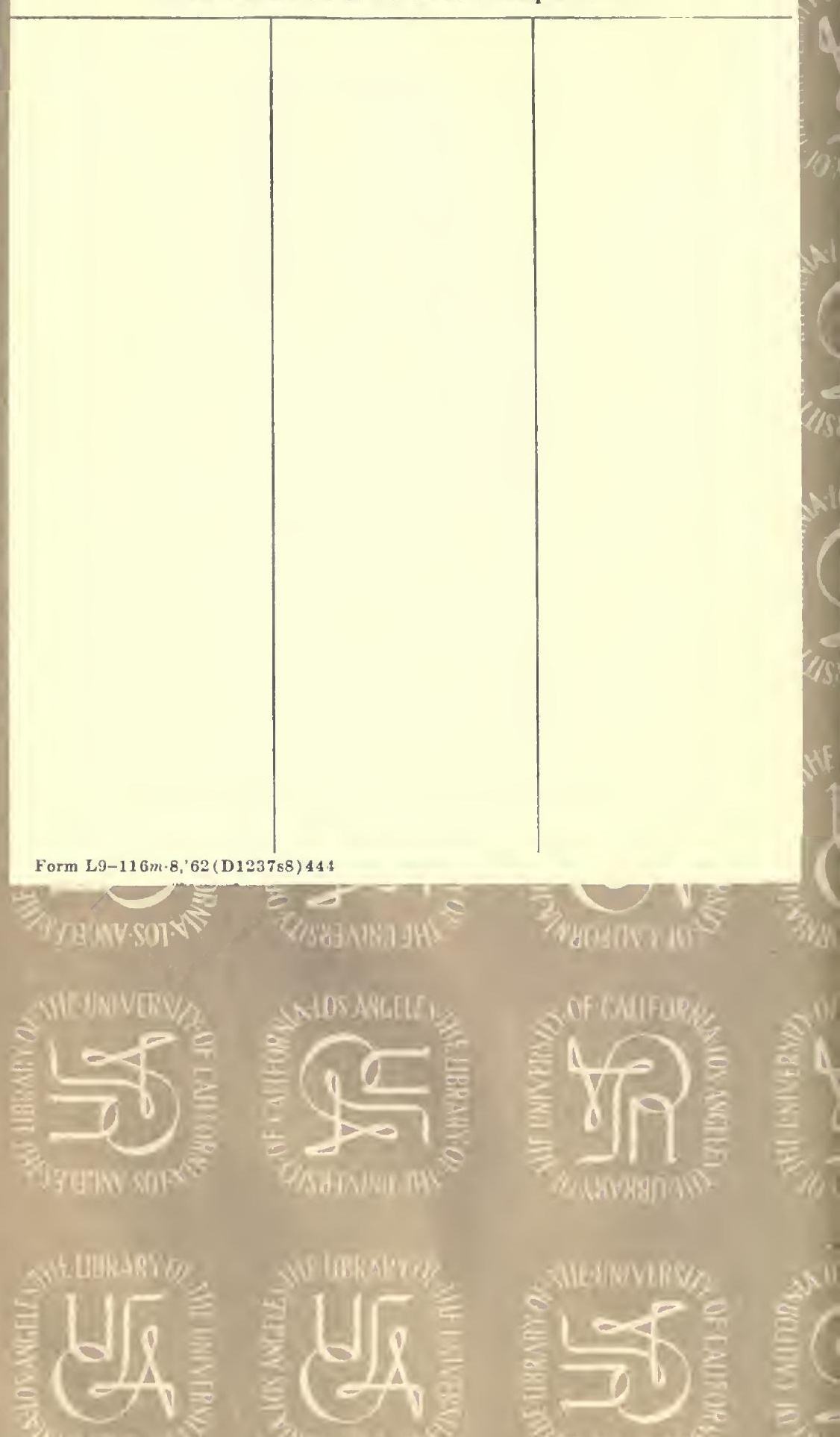


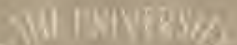

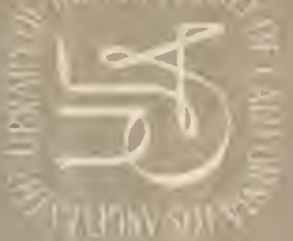

WhIBRAM

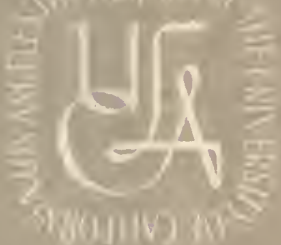

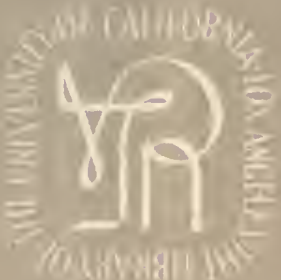

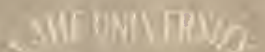

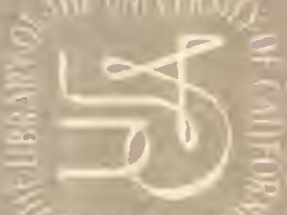

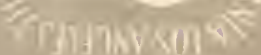

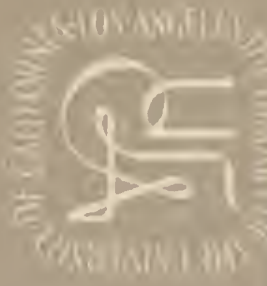

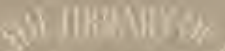
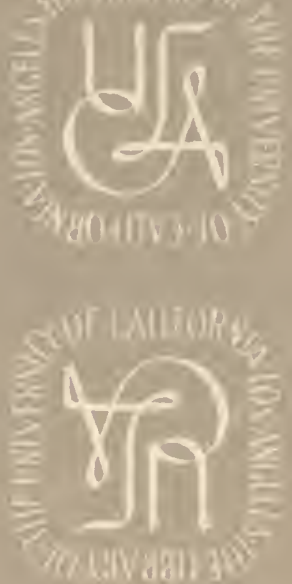

$\frac{1}{2}$

x/A67)

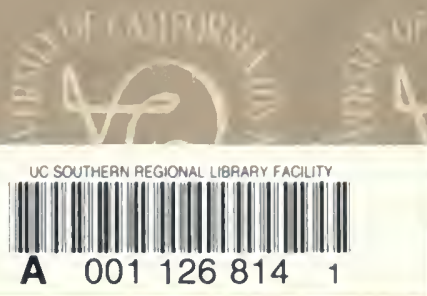

A $001126814 \quad 1$
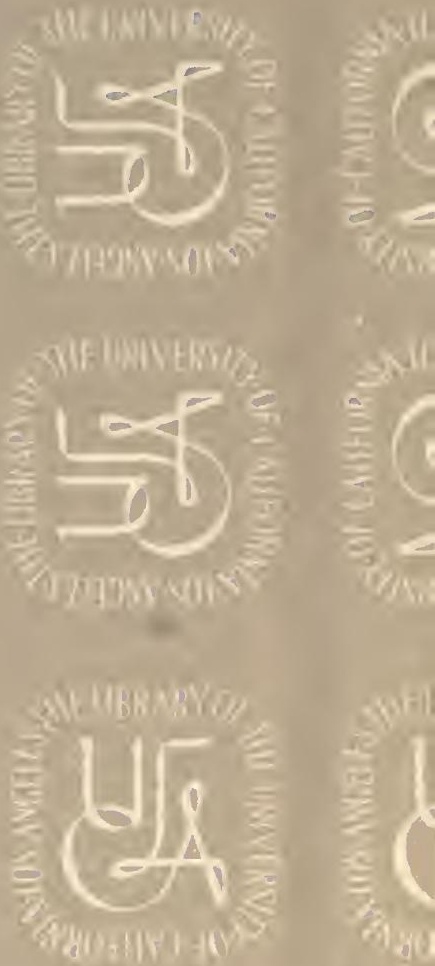

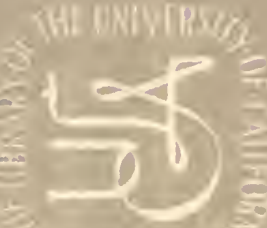

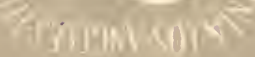
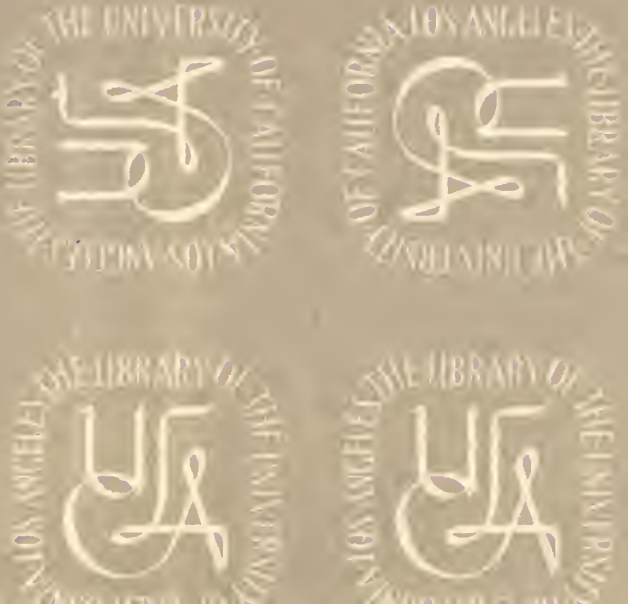

BME IBNABD 0

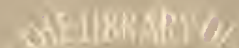

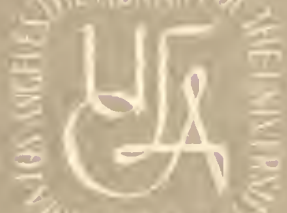

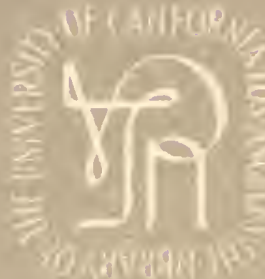

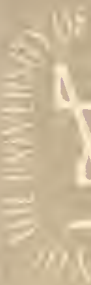

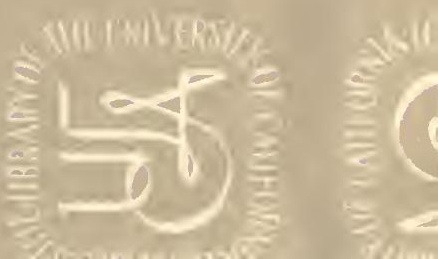




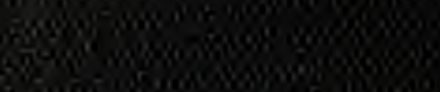

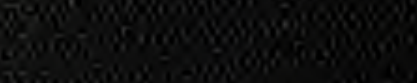

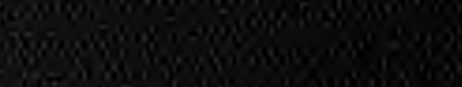

$5 \mathrm{v}$

tos

6. Sox

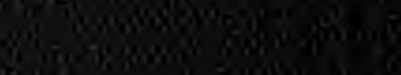

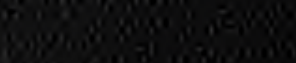

$\cos , 208$

$\sin x$ 